\title{
Perspectivas para a tutela das políticas públicas no estado democrático de direito: a (In)efetividade do controle no desvio de verbas públicas perante ONGs e OSCIPs ${ }^{1}$
}

\author{
Logan Caldas Barcellos ${ }^{2}$
}

\section{Resumo}

Este trabalho tem como objetivo debater algumas das dificuldades do controle exercido pelos tribunais de contas e pelo governo, de modo a observar como essas instituições lidam com a fiscalização das verbas públicas. Partindo do princípio de que as políticas públicas são essenciais para o aprimoramento e constituição do estado social, foi realizada uma análise sobre os sistemas de controle na aplicação de recursos públicos por ONGs e OSCIPS. Em seguida, foram oferecidas sugestões que visam ao aprimoramento das formas de controle de recursos públicos. Assim, vê-se que os tribunais de contas têm um papel fundamental na implementação de políticas públicas em diversas áreas, visto que a fiscalização de verbas por tais entidades pode fortalecer a lisura pública. Além disso, observa-se que a racionalização das despesas públicas e o combate ao desperdício dependem da ação institucional e do fortalecimento dos tribunais de contas para uma melhor aplicação de recursos em políticas públicas.

Palavras-chave: Ordem econômica. Controle externo. Despesas públicas. Estado democrático de direito. Políticas públicas.

\section{Introdução}

O controle do gasto público é uma questão urgente no cenário político brasileiro. Tem sido demonstrado tanto na mídia quanto nos jornais e na doutrina,

1 Este artigo está cadastrado no Digital Object Identifier System sob o número doi: 10.5102/ prismas.2010.07.1.02. Disponível em: <www.publicaçõesacadêmicas. uniceub.br>.

2 Advogado. Mestrando em Direito Público pela UNISINOS - Universidade do Vale do Rio dos Sinos, RS. Especialista em Direito Previdenciário pela Faculdade IDC. Graduado em Direito pela UNISINOS. 
o quanto estamos longe de um processo de racionalização das despesas públicas, visto que grande parte dos recursos é desviada da sua finalidade legal, usada para fins ilícitos que contrariam as noções de justiça e igualdade. Quando a bandeira do Estado Social e Democrático de Direito foi erguida, no início do séc. XX, pregando a igualdade e a garantia dos direitos fundamentais e incorporando ao Estado Liberal novos ideários políticos, imaginava-se que estávamos diante de uma nova realidade e de uma transformação sociopolítica fundamental que modificaria profundamente a estrutura da sociedade e, consequentemente, o Poder Público.

Infelizmente, as grandes expectativas diante de uma reformulação do governo quanto às políticas de ordenação do gasto público fracassaram em grande parte, apesar de todos os esforços feitos na tentativa de alcançar o ideal de uma distribuição justa de bens e serviços públicos. O fato alarmante é que, apesar da ascensão do direito financeiro como um ramo próprio e da propagação da ideologia de cunho social - observe-se que a função social do Direito não significa o desprezo ou o sacrifício dos direitos e garantias individuais, mas antes implica uma coexistência de interesses privados e públicos - pregada no século XX tida como o fundamento das nossas expectativas políticas, ainda estamos muito distantes do ideal, porque os crimes tributários, a ineficácia das instituições e a necessidade de uma reforma administrativa que traga efetividade aos princípios constitucionais do art. 37, caput, da Constituição, no sentido de organizar a máquina pública, visando sua maior eficiência, demonstram que, apesar de todo o progresso havido, ainda resta muito a fazer. Esses problemas representam os entraves que existem à implementação de um Estado Social e Democrático, tornando-se necessário considerar que tais dificuldades não justificam a lesão aos direitos de natureza liberal, aos quais incumbe ao Estado Democrático tutelar. A Constituição Brasileira de 1988 foi idealizada para a realização da democracia social e participativa, mas o processo de exclusão social - falta de satisfação das necessidades mínimas de existência e isolamento entre as classes sociais - obstaculiza tal intento, na medida em que a informação, a educação e a cultura são fundamentais no processo de democratização.

Para modificar essa situação e impulsionar o Brasil para um desenvolvimento da sua Economia, é preciso superar os percalços e suportar os sacrifícios precisos. É necessária não somente uma reforma institucional, mas também uma mudança de mentalidade. É imperioso rever os conceitos fundamentais do Direito e atualizá- 
los diante das necessidades do Estado Social e Democrático; essas são, certamente, medidas extremamente importantes para que o nosso país possa rumar em direção às sonhadas realizações dos ideais sociais. Os crimes cometidos, tais como peculato, concussão, corrupção passiva, emprego irregular de verbas e rendas públicas ${ }^{3}, 0$ superfaturamento de obras e serviços e, ainda, os crimes cometidos em licitações, tais como as fraudes ao caráter competitivo do certame ${ }^{4}$, afetam consideravelmente a sociedade brasileira, sendo preciso: a) uma prevenção, consistente em estudar a probidade dos candidatos a cargos políticos, como atributo prévio ao exercício da função pública; b) uma repressão por parte de todos a tais práticas.

É preciso encontrar alternativas que atenuem os contrastes existentes no Brasil, país em que grande parte da população vive em condições econômicas precárias, enquanto que, por outro lado, as dificuldades institucionais e políticas de controle favorecem aqueles que exploram as fragilidades do sistema sociopolítico, contaminados por um individualismo que corrompe as bases da economia brasileira e ruma na contramão do pensamento intervencionista, ao lesarem o erário público em proveito próprio, apropriando-se de verbas que têm finalidades sociais, dificultando a consecução dos ideais da modernidade - igualdade, liberdade, fraternidade. Consequentemente, esses aspectos contribuem para a crise em que estamos inseridos.

Desse modo, as necessárias mudanças devem sempre partir de uma crítica que seja capaz de envolver os diversos aspectos do problema e buscar alternativas que visem atenuar ou solucionar as dificuldades existentes. Esse é um primeiro passo (político) para a superação do status quo. Para desenvolver este trabalho, primeiramente será exposta a fértil discussão acerca da função e da ideologia do Estado Social e Democrático, englobando seus aspectos históricos e suas dificuldades.

Após isso, serão apresentados diversos aspectos do problema do orçamento público, entre os quais se destacam a função do direito financeiro e uma reconsideração das atribuições dos tribunais de contas e do desperdício de recursos públicos, como questões prementes que exigem da sociedade e do governo uma responsabilidade política. Inicialmente, cumpre observar a evolução do Estado Social e o

\footnotetext{
3 Esses crimes são previstos nos artigos 312, 316, 317 e 315 do Código Penal.

4 Crime previsto no art. 90 da lei 8666/93.
} 
surgimento dos direitos sociais e após, as dificuldades para a sua implementação e a necessidade de aprimoramento incessante de suas políticas públicas pela vedação do retrocesso social, com o intuito de debater acerca de formas de controle dos recursos públicos.

\section{As competências do estado e o direito público}

Segundo a definição de Mello ${ }^{5}$, o Estado, tripartido nas suas funções, deve disciplinar o exercício das atividades administrativas, buscando sempre a máxima eficiência, de modo a assegurar o efetivo cumprimento das demandas públicas. Erigido à função de protetor dos direitos individuais e coletivos, ele deve agir em prol da coletividade a partir das suas instituições e das entidades que colaboram com ele, pois isso é uma tarefa impostergável.

Daí o motivo pelo qual o governo necessita de um conjunto de normas jurídicas administrativas, de cunho instrumental, incluindo as que disciplinam o processo administrativo ${ }^{6}$, para atingir os fins propostos na Carta Magna de 1988 e nos ideais democráticos. Segue-se daí que o direito administrativo é composto de um regime jurídico próprio, disciplinador das competências públicas. Na opinião de $\mathrm{Mello}^{7}$, os princípios do regime jurídico administrativo, em linhas gerais, são 14: 1) o princípio da supremacia do interesse público sobre o interesse privado; 2) o princípio da legalidade; 3 ) o princípio da finalidade; 4) o princípio da razoabilidade; 5) o princípio da proporcionalidade; 6) o princípio da motivação; 7) o princípio da impessoalidade; 8) o princípio da publicidade; 9) os princípios do devido processo legal e da ampla defesa; 10) o princípio da moralidade administrativa; 11) o princípio do controle judicial dos atos administrativos; 12) o princípio da

\footnotetext{
${ }^{5}$ MELLO, Celso Antônio Bandeira de. Curso de direito administrativo. 18. ed. São Paulo: Malheiros, 2005. p. 28.

${ }^{6}$ A respeito do processo administrativo, na esfera federal a lei que o rege é a Lei 9784/99, com as alterações que sofreu pelas Leis 8883/94 e 9648/98; a lei nacional regente das licitações, em todos os entes da Federação, porquanto é constituída de normas de caráter geral, é a Lei 8666/93, que institui princípios e preceitos jurídicos, apesar de os Municípios, Estados e o Distrito Federal terem competência para legislar acerca da licitação, desde que não conflitem com a Lei 8666/93.

7 MELLO, Celso Antônio Bandeira de. Curso de direito administrativo. 18. ed. São Paulo: Malheiros, 2005. p. 114.
} 
responsabilidade do Estado por atos administrativos; 13) o princípio da eficiência; e 14) o princípio da segurança jurídica.

O Estado, legitimado pela Constituição e pela sociedade, pode ser considerado como um corpo orgânico, no qual as funções dos seus órgãos visam à harmonia do todo, evitando incongruências ou perturbações. Daí porque o governo está fadado ao cumprimento de regras de direito público, já que, segundo o art. $1^{\circ}, \$ 1^{\circ}$ da Constituição, "todo o poder emana do povo, que o exerce por meio de representantes eleitos ou diretamente, nos termos desta Constituição”.

É, pois, o direito público, diversamente do direito privado, volvido intrinsecamente à consecução do interesse público, em contraposição ao segundo, que tutela interesses individuais ${ }^{8}$. O direito público, disciplinador das funções do Estado, tem por escopo servir à coletividade e, por isso, seus variados ramos, como o direito constitucional, tributário, eleitoral, administrativo, financeiro e penal, com princípios próprios e regimes jurídicos correspondentes, devem servir a esse fim. Na consecução desse desiderato, o Poder Público deve sempre visar atender ao interesse público, que é a “dimensão pública dos interesses individuais”, para Mello".

\section{A genealogia dos direitos sociais}

A genealogia dos direitos sociais é fundada no constitucionalismo do século XX, pois foi somente nesse século que surgiram sistemas jurídicos fundados na ideia de proteção dos direitos coletivos, como o direito do trabalho e, com ele, foram dados largos passos para a diminuição das desigualdades sociais.

É a partir do século XX que se iniciou a universalização dos direitos sociais. A respeito disso, diz José Afonso da Silva ${ }^{10}$ :

${ }^{8}$ Conquanto a dicotomia entre direito público e privado tenha sofrido inúmeras críticas em razão da sua insuficiência para classificar todos os ramos do Direito, inclusive o direito do trabalho, que tem um âmbito individual e outro coletivo ou social, buscamos referir que o interesse público é um princípio central do direito público, especialmente do direito administrativo.

9 MELLO, Celso Antônio Bandeira de. Curso de direito administrativo. 18. ed. São Paulo: Malheiros, 2005. p. 57.

${ }^{10}$ SILVA, José Afonso da. Curso de direito constitucional positivo. 24. ed. São Paulo: Malheiros, 2005. p. 160. 
No plano jurídico, a Revolução de 1848, em Paris, inscreveu, em sua constituição de curta duração, o direito do trabalho, mas foi a Constituição mexicana de 1917 que, por primeiro, sistematizara o conjunto dos direitos sociais do homem, restrita, no entanto, ao critério de participação estatal na ordem econômica e social, sem romper, assim, em definitivo, com o regime capitalista. A Declaração dos Direitos Sociais (trabalho e previdência social) consta do extenso art. 123 daquele documento constitucional, ainda em vigor. No mesmo sentido, seguiu-se a Constituição alemã de Weimar, de 1919, abrindo seu Livro II com a rubrica dos Direitos e Deveres Fundamentais dos Alemães, sob a qual inclui os direitos da pessoa individual (cap. I), os direitos da vida social (cap. II), os da vida religiosa (cap. III), os da educação e escola (cap. IV) e os da vida econômica (cap. V). Os direitos sociais e econômicos, dentro do regime capitalista, estão reconhecidos e garantidos ao lado dos direitos individuais, como na Constituição mexicana, que é mais avançada do que aquela. Mas foi a de Weimar que exercera maior influência no constitucionalismo de pósPrimeira Guerra Mundial, até na brasileira de 1934.

A Revolução de 1848, a Constituição Mexicana de 1917 e a Constituição de Weimar de 1919 significaram a eclosão do Estado Social, que se contrapõe ao Estado Liberal. O Estado Liberal tinha como características, segundo Schilling ${ }^{11}$ : a) individualismo; b) valorização da propriedade privada; c) um ideal de liberdade política e econômica; d) meritocracia, consistentes em privilégios econômicos e políticos aos nobres e aos proprietários. Diz Schilling ${ }^{12}$ que o termo "Liberalismo" foi empregado pela primeira vez em 1823, por Claude Boiste, e a expressão "liberal” foi utilizada no Journal d'Argenson, em 1750, conquanto as raízes do pensamento liberal sejam mais remotas e possam ser encontradas nos finais do século XVII e início do século XVIII. O Liberalismo é um fruto do pensamento político dos burgueses, que queriam concentrar o poder político em suas mãos, através do direito à representação. O Liberalismo tem um aspecto político e econômico: o liberalismo político buscou limitar as possibilidades despóticas do Estado, realçando os direitos de liberdade; nele, o Estado de Direito, governado pela Constituição,

\footnotetext{
${ }^{11}$ SCHILLING, Voltaire. As grandes correntes do pensamento. 2. ed. Porto Alegre: AGE, 1999. p. 92.

${ }^{12}$ SCHILLING, Voltaire. As grandes correntes do pensamento. 2. ed. Porto Alegre: AGE, 1999. p. 91.
} 
submete-se ao império das leis. O liberalismo econômico é um resultado do desenvolvimento da "economia política", tendo sido influenciado por François Quesnay, com a obra "O quadro econômico", de 1758, e Adam Smith, com "A riqueza das nações”, em 1776. Condenava o intervencionismo econômico do Estado, pregando o direito à liberdade econômica, ou seja, conduzindo à livre concorrência. Desse modo, a estipulação de preços ficava sujeita às variações do mercado. Nesse sentido, representava um ideal de liberdade não somente formal, mas material: almejava-se propiciar as condições necessárias para que a liberdade não fosse cerceada, apesar de, na prática, continuarem a existir desigualdades entre os cidadãos.

Bonavides ${ }^{13}$ sustenta a ideia de que a filosofia política liberal tinha como cernes fundamentais a ideia de separação dos poderes, princípio de Montesquieu que foi aperfeiçoado pelo constitucionalismo, e a supremacia do Legislativo sobre os demais poderes; o fundamento disso é claro: o liberalismo político tinha a intenção de limitar o poder, e para isso o Poder Legislativo foi designado com a função de garantir os direitos individuais. A moderna Teoria do Estado passou a admitir, com o advento da crise do Liberalismo, que ele não satisfazia os interesses coletivos e foi então que a concepção organicista, que concebe o Estado como um organismo em que todos devem ser solidários, suplantou o individualismo da ideologia liberal ${ }^{14}$.

A ideia de Estado, portanto, passou por uma radical transformação. Os teóricos do Liberalismo, fundados na ideia do contrato social, como Rousseau, e do estado de natureza, em Hobbes e Locke, contribuíram para o fortalecimento dos direitos subjetivos; o Liberalismo tinha, porém, uma visão negativa sobre o Estado, em grande parte em razão das arbitrariedades cometidas durante o absolutismo

${ }^{13}$ BONAVIDES, Paulo. Do estado liberal ao social. São Paulo: Malheiros, 2004. p. 79.

${ }^{14}$ MELLO, Celso Antônio Bandeira de. Curso de direito administrativo. 18. ed. São Paulo: Malheiros, 2005. p. 218. Por exemplo; na Sociologia, Émile Durkeim é uma referência do modelo organicista. BONAVIDES, Paulo. Do estado liberal ao social. São Paulo: Malheiros, 2004. p. 135. Alerta que essa concepção afirma a necessidade das partes se submeterem ao todo, e quase sempre justifica, de forma ostensiva ou dissimulada, a tirania. Savigny, em seu livro de 1814, sustenta essa concepção. Uma das mais fortes críticas ao organicismo é feita por Kelsen, na sua "Teoria Geral do Estado". A posição organicista, porém, tem origens mais antigas: remonta ao pensamento grego e ao estoicismo: Platão, Aristóteles, Cícero e Sêneca o admitiam. 
francês, afirmam Morais e Streck ${ }^{15}$. A crise política do Liberalismo teve uma série de causas, mas, certamente, a principal foi a necessidade de transformar o status quo, ou seja, o perfil clássico e individualista do pensamento liberal não atendia às novas necessidades sociais.

O Estado Social, diferentemente do Estado Liberal, é intervencionista. Ele avoca a responsabilidade de implementar e gerenciar políticas públicas. O Estado Social, portanto: a) diminui o âmbito de liberdade do indivíduo, em razão do desaparecimento do Estado mínimo, que não intervinha na economia; b) assume uma postura ativa, portanto, interfere na esfera política e econômica: passa a ser um agente normativo no domínio econômico e a buscar a concretização das políticas públicas. Adota um “dirigismo” e um “intervencionismo”.

São fatos que motivaram o surgimento do Estado Social, segundo Morais e Streck ${ }^{16}$ : a) a Revolução Industrial e as suas consequências, entre as quais estão a urbanização, as necessidades de políticas sociais tais como transporte, saúde, saneamento, a degradação ambiental e as mudanças nas condições de trabalho e na previdência; b) a Primeira Guerra Mundial acarreta a derrocada do liberalismo econômico, pois amplia as exigências de armamento e aprovisionamento, também sob a influência da Revolução Russa de 1917, da Constituição de Weimar de 1919, da Constituição Mexicana; c) a Crise Econômica de 1929 e a Depressão demonstram que a estabilidade só pode ser alcançada através da ação governamental e da iniciativa privada; d) a Segunda Guerra Mundial exige o controle dos recursos sociais. O Welfare State é, então, uma transformação do pensamento liberal. A respeito disso, afirmam Morais e Streck ${ }^{17}$ :

Em virtude disso, pode-se dizer que o Estado do BemEstar Social constitui uma experiência concreta da total disciplina pública da economia, assumido como modelo de futuros objetivos autoritários da política econômica e ao mesmo tempo cria hábitos e métodos dirigistas dificilmente anuláveis.

\footnotetext{
${ }^{15}$ MORAIS, José Luis Bolzan de; STRECK, Lenio Luiz. Ciência política e teoria geral do Estado. 4. ed. Porto Alegre: Livraria do Advogado, 2004. p. 56.

${ }^{16}$ MORAIS, José Luis Bolzan de; STRECK, Lenio Luiz. Ciência política e teoria geral do Estado. 4. ed. Porto Alegre: Livraria do Advogado, 2004. p. 63.

${ }^{17}$ MORAIS, José Luis Bolzan de; STRECK, Lenio Luiz. Ciência política e teoria geral do Estado. 4. ed. Porto Alegre: Livraria do Advogado, 2004. p. 65.
} 
Um dos economistas que certamente teve grande influência na concepção do Estado Social foi John Maynard Keynes (1883-1946), por ser um grande observador das políticas macroeconômicas e trazer uma série de férteis críticas acerca delas, exigindo a intervenção econômica do Estado, dentro da era capitalista, sempre dentro de um viés volvido à distribuição da riqueza por meio da livre iniciativa. Os liberais questionavam, entretanto, os limites da intervenção estatal. As exigências econômicas demonstravam que, sem o Estado, facilmente eram constituídos monopólios econômicos, o que era contrário aos interesses econômicos da sociedade, logo, nos EUA surgiram leis antitruste. A existência de crises econômicas, a ascensão do Socialismo, a necessidade de políticas trabalhistas e os efeitos econômicos das guerras mundiais desencadearam a necessidade de um "dirigismo econômico". A burguesia se via na iminência de perder seus privilégios e, pressionada pelas conjunturas políticas e econômicas, teve de abrogar da sua ideologia e ceder ante as exigências sociais, tal qual já havia ocorrido no período absolutista, com a monarquia. Nesse sentido, diz Copetti ${ }^{18}$ :

Cede assim o Estado liberal-burguês às exigências dos trabalhadores. Entrega os anéis para não perder os dedos, vendo-se forçado a conferir, constitucionalmente, direitos do trabalho, da previdência, da educação, a ditar o salário, a manipular a moeda, a intervir na economia como distribuidor, a comprar a produção, regular preços, combater o desemprego, proteger o trabalhador, controlar as profissões, enfim, passa a intervir na dinâmica socioeconômica da sociedade civil.

O new deal americano de Roosevelt, que visava superar as conjunturas financeiras, o keynesianismo, a crise de 1929, a transformação da sociedade de agrária em industrial e a luta pelos direitos tiveram um impacto positivo na mudança da ideologia. o État Providence foi gestado a partir de causas políticas, econômicas, sociais, jurídicas e éticas. Tudo isso ocorreu em função da ideia de justiça social, que passou a emergir de um campo de reivindicações. A constatação de que era preciso mais que um ideal de liberdade, face às profundas desigualdades sociais e econômicas conduziu a sociedade a uma ânsia de igualdade, "entendida não apenas como possibilidade formal, mas também como articulação de uma sociedade

${ }_{18}$ COPETTI, André. Direito penal e estado democrático de direito. Porto Alegre: Livraria do Advogado, 2000. p. 54. 
justa"19 e "asseguramento jurídico de condições mínimas de vida ao cidadão e à comunidade" 20 .

O reconhecimento constitucional dos direitos sociais está na nossa atual Constituição ${ }^{21}$. Os direitos sociais são, para Silva ${ }^{22}$ : “[...] imposições constitucionais”. Morais e Streck ${ }^{23}$ denunciam, entretanto, que, apesar de a Constituição de 1988 estar repleta de normas de cunho social, há uma profunda disparidade entre o real e o ideal: o Estado Social e a Democracia, no Brasil, ainda são incipientes; a modernidade brasileira é um simulacro e está em crise, pois, embora o projeto político do Estado Social seja redistributivista e pregue uma política igualitária, há uma prodigalidade para com as elites, os "burgueses da atualidade".

Dentro do cenário do neoliberalismo, que revolve à ideologia liberal das camadas profundas do pensamento político, há uma tentativa de reviver o liberalismo clássico com uma nova roupagem marcada pela globalização, dentro de um mundo totalmente diferente, distante do século XVIII. Os neoliberais, portanto, querem um Estado Mínimo em plena era da globalização, enquanto os defensores do Estado Social querem um Estado intervencionista, que diminua as margens de liberdade do mercado, com o intuito de promover a igualdade, entendida como acesso às condições mínimas de vida por todos.

O problema estrutural da sociedade política moderna é transpassar o Estado Social do domínio do discurso para a realidade. Em que pese os avanços causados pela Constituição de 1988, grande parcela da população ainda não viveu plenamente os seus direitos sociais, apregoados no art. $6^{\circ}$, caput da Constituição.

${ }^{19}$ MORAIS, José Luis Bolzan de; STRECK, Lenio Luiz. Ciência política e teoria geral do Estado. 4. ed. Porto Alegre: Livraria do Advogado, 2004. p. 93.

${ }^{20}$ MORAIS, José Luis Bolzan de; STRECK, Lenio Luiz. Ciência política e teoria geral do Estado. 4. ed. Porto Alegre: Livraria do Advogado, 2004. p. 97.

${ }^{21}$ Os direitos sociais estão consubstanciados nos artigos $6^{\circ}$ a 11,170 a 192 e 192 a 232 da Constituição de 1988. O art. 6 o da Constituição diz que "São direitos sociais a educação, a saúde, o trabalho, a moradia, o lazer, a segurança, a previdência social, a proteção à maternidade e a infância, a assistência aos desamparados, na forma desta Constituição".

${ }^{22}$ SILVA, José Afonso da. Aplicabilidade das normas constitucionais. 6. ed. São Paulo: Malheiros, 2004. p. 151.

${ }^{23}$ MORAIS, José Luis Bolzan de; STRECK, Lenio Luiz. Ciência política e teoria geral do Estado. 4. ed. Porto Alegre: Livraria do Advogado, 2004. p. 128. 
Enquanto o Estado Liberal estava fundado no princípio da legalidade, hoje consubstanciado no art. $5^{\circ}$, II, da Constituição, o Estado Social está baseado na ideia da legitimidade social, ou seja, é aceito como promotor de políticas públicas volvidas à questão social, pois "legítima é a gestão da coisa pública fundada no bem-estar da maioria de um povo" ${ }^{24}$. Os direitos sociais tiveram ainda outro desenvolvimento: o despertar da democracia a partir da atual Constituição. Cunha ${ }^{25}$ enuncia bem a distinção entre legalidade e legitimidade: enquanto a legalidade importa apenas na adequação do comportamento ao comando legal, a legitimidade exige o apoio ou embasamento dos governantes nos objetivos da comunidade, em suas tradições e costumes, ou seja, a legalidade é conceito formal, e a legitimidade abarca todo um conjunto de crenças comuns de aceitação popular.

O Estado Democrático de Direito não somente é intervencionista, mas também visa qualificar o debate político por meio da participação dos cidadãos. O Estado Democrático visa transformar o status quo, mas com um cunho profundamente igualitário. O princípio da legalidade, segundo a concepção democrática, tem como finalidade a isonomia. A democracia é, então, uma grande aquisição do constitucionalismo, mas ainda resta um grande conjunto de propostas não cumpridas e de obstáculos à concretização democrática, entre os quais se pode destacar um dos principais, que é o "déficit de representatividade". Nesse aspecto, não somente pode ser discutido o sistema proporcional, como também o problema da "legitimação democrática" na medida em que o mandato político não tem apenas um significado simbólico: deve ser, acima de tudo, uma vivência em prol da coletividade, algo que, na prática, muitas vezes não ocorre, pois interesses pessoais e pressões dos partidos podem influir na decisão política, muitas vezes em detrimento da sociedade, expondo a fragilidade do nosso modelo democrático ${ }^{26}$.

${ }^{24}$ CHIMENTI, Ricardo Cunha; et al. Curso de direito constitucional. 4. ed. São Paulo: Saraiva, 2007. p. 290.

${ }^{25}$ CUNHA, Fernando Whitaker da. Teoria geral do Estado: introdução ao direito constitucional. Rio de Janeiro: Freitas bastos, 1990. p. 82.

${ }^{26}$ MORAIS, José Luis Bolzan de; STRECK, Lenio Luiz. Ciência política e teoria geral do Estado. 4. ed. Porto Alegre: Livraria do Advogado, 2004. p. 104. 


\section{0 contexto econômico do estado democrático de direito e o princípio da vedação de retrocesso social}

Faria ${ }^{27}$ expõe as dificuldades do Estado na Economia globalizada, demonstrando a complexidade do problema do orçamento público. Ele aborda os problemas do Direito na era econômica keynesiana, que, segundo ele, são a ingovernabilidade sistêmica e ineficácia jurídica. Essas questões têm relação com as políticas macroeconômicas, inspiradas no problema da recessão econômica dos anos 20, que trazem à tona duas perguntas: a) qual é a capacidade da administração pública para governar, ordenar e disciplinar o sistema econômico?; e b) qual é a sua estrutura para enfrentar grandes depressões econômicas? Keynes teve importância pelas suas críticas ao mercado, principalmente às políticas macroeconômicas; naquela época, muitos não acreditavam no Estado como regulador da Economia, mas Keynes foi um precursor do intervencionismo.

A tensão entre governabilidade, democracia e eficiência continua imperando no cenário econômico, já que, segundo Faria年, a "situação-limite" da crise de governabilidade ocorre na crise fiscal, na qual as despesas crescem mais rapidamente do que os meios de financiá-las, gerando uma insustentabilidade econômica que leva os governos à sobrecarga tributária; as políticas econômicas implementadas não podem mais regredir, porque se tornaram direitos sociais; a sociedade não admite perder esses direitos conquistados, obrigando o Estado, mesmo em situações de crise econômica, a manter as suas políticas, o que pode gerar um desequilíbrio orçamentário. Ainda segundo Faria ${ }^{29}$ :

Esse é o fator responsável pela crise fiscal. Por causa da inexorável propensão dessas despesas a se expandirem numa velocidade muito acima da suportável pela estrutura econômica, o Estado se vê obrigado a transferir, por vias tributárias, os excedentes do sistema político e a reduzir a capacidade pública e privada de investimento desse mesmo sistema.

O tema da proibição de retrocesso das políticas econômicas é correlato aos das "cláusulas de proibição do retrocesso social", as quais são asseguradas pela ordem

\footnotetext{
${ }^{27}$ FARIA, José Eduardo. O direito na economia globalizada. São Paulo: Malheiros, 2004. p. 113.

${ }^{28}$ FARIA, José Eduardo. O direito na economia globalizada. São Paulo: Malheiros, 2004. p. 119.

${ }^{29}$ FARIA, José Eduardo. O direito na economia globalizada. São Paulo: Malheiros, 2004. p. 120.
} 
constitucional e visam impedir que direitos sociais venham a sofrer abalos em função de decisões políticas ou econômicas que venham a desestabilizá-los. Sarlet ${ }^{30}$ demonstra que o "princípio da vedação de retrocesso social" tem guarida na Constituição de 1988 e consagra principalmente a proteção do núcleo dos direitos sociais, ou seja, a Constituição deve ser vinculante quanto ao legislador ordinário, que não pode simplesmente revogar aquilo que foi estipulado pelo Poder Constituinte Originário.

Segundo Sarlet ${ }^{31}$, o "Princípio implícito da proibição de retrocesso na ordem constitucional brasileira" pode ser aduzido pelas seguintes razões, que não são exaustivas: a) o fundamento do Estado Social e Democrático de Direito impõe o princípio da segurança jurídica; b) o princípio da dignidade da pessoa humana determina medidas e prestações que devem viabilizar o seu desenvolvimento e, que, portanto, não podem cessar; c) o princípio da máxima eficácia e efetividade das normas definidoras de direitos fundamentais, pelo art. $5^{\circ}, \$ 1^{\circ}$, estipula que "as normas definidoras dos direitos e garantias fundamentais têm aplicação imediata"; d) as manifestações da Constituição, que se constituem em cláusulas pétreas expressas, como a proteção dos direitos adquiridos, da coisa julgada e do ato jurídico perfeito, fazem parte do princípio da segurança jurídica, mas não o esgotam, devendo, portanto, haver um asseguramento dos direitos previstos no art. $5^{\circ}$, caput da Constituição; e) o princípio da proteção da confiança, decorrente da boa-fé que os indivíduos depositam no regime constitucional, deve ser mantido; f) os órgãos do Estado estão vinculados às imposições constitucionais e aos atos anteriores; e g) o questionamento e a revogação de normas constitucionais protetivas dos interesses sociais significa um atentado à ordem constitucional, além de ser uma afronta à vontade expressa do Constituinte. Poderia ser acrescentada também a ideia de legitimidade política, segundo a qual as decisões dos governantes devem ser pautadas pela aceitação social, e, logo, não podem contrariar os direitos sociais. Fica claro que tais argumentos são, antes de tudo, corolários do desenvolvimento do Constitucionalismo. Isto será exposto no esquema a seguir:

\footnotetext{
${ }^{30}$ SARLET, Ingo. Direitos fundamentais sociais e proibição de retrocesso: algumas notas sobre o desafio da sobrevivência dos direitos sociais num contexto de crise. Revista do Instituto de Hermenêutica Jurídica, Porto Alegre, v. 1, n. 2, p. 138, anual, 2004.

31 SARLET, Ingo. Direitos fundamentais sociais e proibição de retrocesso: algumas notas sobre o desafio da sobrevivência dos direitos sociais num contexto de crise. Revista do Instituto de Hermenêutica Jurídica, Porto Alegre, v. 1, n. 2, p. 146, anual, 2004.
} 


\section{Fundamentos jurídico-constitucionais do princípio da vedação de retrocesso social (elaborado a partir de Ingo Sarlet)}

\begin{tabular}{|c|c|}
\hline $\begin{array}{l}\text { Princípio da vedação } \\
\text { de retrocesso social }\end{array}$ & $\begin{array}{l}\text { Fundamentos } \\
\text { jurídico-constitucionais }\end{array}$ \\
\hline a) princípio da segurança jurídica & $\begin{array}{l}\text { Art. } 5^{\circ} \text {, caput e XXXVI da Constituição } \\
\text { da República }\end{array}$ \\
\hline $\begin{array}{l}\text { b) princípio da dignidade da pessoa } \\
\text { humana }\end{array}$ & Art. $1^{\circ}$, III da Constituição da República \\
\hline $\begin{array}{l}\text { c) princípio da máxima efetividade } \\
\text { das normas definidoras de direitos } \\
\text { fundamentais }\end{array}$ & $\begin{array}{l}\text { Art. } 5^{\circ} \text {, } \S 1^{\circ} \text { da Constituição da Repú- } \\
\text { blica }\end{array}$ \\
\hline $\begin{array}{l}\text { d) medidas de asseguramento dos } \\
\text { direitos previstos no art. } 5^{\circ} \text {, caput da } \\
\text { Constituição da República }\end{array}$ & $\begin{array}{l}\text { Art. } 5^{\circ} \text {, LXVIII, LXIX, LXX, LXXI, LXXII, } \\
\text { LXIII da Constituição }\end{array}$ \\
\hline e) princípio da proteção da confiança & $\begin{array}{l}\text { Princípio da boa-fé depositada no re- } \\
\text { gime constitucional }\end{array}$ \\
\hline $\begin{array}{l}\text { f) vinculação dos órgãos do Estado } \\
\text { às imposições constitucionais e aos } \\
\text { atos anteriores }\end{array}$ & $\begin{array}{l}\text { Princípio da segurança jurídica e pro- } \\
\text { teção da confiança }\end{array}$ \\
\hline $\begin{array}{l}\text { g) vontade do Poder Constituinte } \\
\text { Originário e integridade da ordem } \\
\text { constitucional }\end{array}$ & $\begin{array}{l}\text { Art. } 60, \S 4^{\circ} \text { da Constituição e seus in- } \\
\text { cisos }\end{array}$ \\
\hline
\end{tabular}

As normas constitucionais são hierárquicas e difundem os seus efeitos sobre todo o ordenamento jurídico; a Constituição é o fundamento de validade da ordem jurídica. O princípio da máxima efetividade da Constituição é um cânone hermenêutico que exige que o intérprete, ao considerar a norma constitucional, dentre os vários sentidos possíveis, opte pelo que dá mais eficácia aos direitos fundamentais. Logo, entendimentos políticos que contrariem o cerne fundamental dos direitos sociais, trazendo um retrocesso constitucional, atuam contra o dirigismo constitucional e os interesses públicos.

O Estado Social e Democrático, como um "agente normativo e regulador da atividade econômica", conforme o art. 174, caput da Constituição de 1988, deve, segundo Faria ${ }^{32}$, para cumprir esse desiderato constitucional, passando a gerir com

\footnotetext{
${ }^{32}$ FARIA, José Eduardo. O direito na economia globalizada. São Paulo: Malheiros, 2004. p. 122.
} 
eficiência o orçamento público, enfrentar: a) a "inflação legislativa”, que consiste na multiplicação desenfreada de leis de caráter "circunstancial", as quais visam responder a problemas específicos e que acabam impedindo a certeza jurídica e negando os direitos conquistados; b) a “juridificação”, no seu sentido negativo, que é o de juridificar o confronto entre capital e trabalho, substituindo as decisões político-ideologicas pelas técnico-jurídicas. Para explicar melhor o conceito de "juridificação" empregado pelo autor, remetemos às considerações de Morais e Streck ${ }^{33}$, que afirmam que um dos problemas da prática do Estado de Direito é:

[...] a possibilidade de que mais do que garantir e promover interesses sociais apresente-se como mecanismo de opressão, utilizando-se da juridicização integral do cotidiano das relações sociais, construindo a realidade tomando como paradigma o prisma jurídico. Seu caráter retórico-argumentativo serve, inclusive, de vínculo redutor da política no debate público.

Existe, portanto, um dilema estrutural no Estado Social e Democrático: deve responder eficientemente às necessidades sociais, realizando a sua função de promoção de políticas públicas e desenvolvimento social, mesmo ante as crises econômicas e as dificuldades políticas, ou seja, não pode retroceder através de reformas (in)constitucionais e também não pode extinguir ou afetar o desenvolvimento de públicas, mesmo diante da mudança de governo, em razão de contingências econômicas.

Isso exige um apelo cada vez maior aos recursos financeiros da população, pois o Estado Social, para ser intervencionista, carece de verbas e programas sociais, o que acarreta a crise fiscal. É, então, que surgiu o direito financeiro como disciplina autônoma ${ }^{34}$ que compreende o "conjunto de normas sobre todas as institui-

${ }^{33}$ MORAIS, José Luis Bolzan de; STRECK, Lenio Luiz. Ciência política e teoria geral do Estado. 4. ed. Porto Alegre: Livraria do Advogado, 2004. p. 99.

${ }^{34}$ BALEEIRO, Aliomar; DERZI, Misabel Abreu Machado. Direito tributário brasileiro. 11. ed. Rio de Janeiro: Forense, 2005. p. 3. Segundo Baleeiro, um precursor do direito financeiro, no início do século XX, é o Barão V.Myrbach Rheinfeld, com sua obra de 1910, mas foi somente após a Primeira Guerra Mundial que surgiu um conjunto de juristas, defensores da autonomia do direito financeiro. $\mathrm{O}$ direito financeiro divide-se no direito tributário, no direito penal fiscal e no direito internacional tributário. A expressão "direito fiscal", atualmente, é considerada sinônimo de "direito tributário", conquanto no começo do século XX o termo "direito fiscal" fosse usado na França para designar um conjunto de normas que disciplinava impostos específicos, como o de transmissão sobre bens imóveis. 
ções financeiras - receitas, despesas, orçamento, crédito e processo fiscal", segundo Baleeiro $^{35}$, ao passo que o direito tributário aplica-se somente às receitas de caráter compulsório. O Estado Social tem uma índole tributarista e depende do orçamento público para a consecução dos seus objetivos, mas está fadado a um dilema: deve fazer face às crises econômicas mediante um crescente desenvolvimento e a utilização dos recursos públicos, mas não deve recuar no campo das conquistas sociais, pois senão estará violando o princípio da proibição do retrocesso social.

\section{0 desvio de verbas federais pelas Organizações da Sociedade Civil de Interesse Público (OSCIPs) e Organizações Não-governamentais (ONGs) e as políticas públicas}

Segundo a definição de Rosa Júnior ${ }^{36}$ :

Direito Financeiro é o ramo do direito público que estuda o ordenamento jurídico das finanças do Estado e as relações jurídicas decorrentes de sua atividade financeira e que se estabeleceram entre o Estado e o particular.

Ele compreende, portanto, o estudo da despesa pública, da receita pública, do crédito público e do orçamento público. O direito financeiro tem instituídos os seus princípios na Constituição de 1988; o direito financeiro está nos artigos 145 a 169 do texto constitucional. Campos ${ }^{37}$, no título "Teoria Jurídica dos Gastos Públicos", elenca os requisitos para a previsão das despesas públicas que são a utilidade, possibilidade contributiva, discussão pública, oportunidade, legitimidade e legalidade. O direito tributário faz parte do direito financeiro, mas tem um aspecto essencial que o caracteriza: a compulsoriedade. É indubitável que:

[...] as mais significativas receitas públicas - do ponto de vista quantitativo e qualitativo - são as receitas tributárias, que encontram seu fundamento na existência de um dever genérico de cobertura dos encargos públicos ${ }^{38}$.

\footnotetext{
${ }^{35}$ BALEEIRO, Aliomar; DERZI, Misabel Abreu Machado. Direito tributário brasileiro. 11. ed. Rio de Janeiro: Forense, 2005. p. 5.

${ }^{36}$ ROSA JUNIOR apud CAMPOS, Dejalma de. Direito financeiro e orçamentário. 2. ed. São Paulo: Atlas, 2001. p. 36.

${ }^{37}$ CAMPOS, Dejalma de. Direito financeiro e orçamentário. 2. ed. São Paulo: Atlas, 2001. p. 50.

${ }^{38}$ CAMPOS, Dejalma de. Direito financeiro e orçamentário. 2. ed. São Paulo: Atlas, 2001. p. 59.
} 
O direito orçamentário tem a finalidade principal de coordenar as despesas públicas. São os princípios jurídicos do orçamento, consagrados pela Constituição: $o$ princípio da unidade (art. 165, $\$ 8^{\circ}$ da Constituição), que exige somente um documento orçamentário para prever os gastos públicos; o princípio da anualidade (art. 165, III da Constituição), o qual determina que o orçamento público seja ordenado para um exercício financeiro anual, inclusive para que ele possa ser alterado face às oscilações econômicas; o princípio da universalidade (art. 165, $\S$ $5^{\circ}$ da Constituição), segundo o qual, as despesas e receitas em geral devem ser incluídas no orçamento; e o princípio da especificação (art. 165, $\$ 6^{\circ}$ da Constituição de 1988) o qual estipula que as receitas sejam discriminadas de maneira específica, facilitando a clareza e a compreensão do orçamento público ${ }^{39}$.

O art. 165 da Constituição determina a existência de três leis orçamentárias: $a$ lei do plano plurianual, a lei de diretrizes orçamentárias e a lei orçamentária anual. A lei do plano plurianual planeja o orçamento público durante todo o período do mandato do Presidente da República, de forma regionalizada. A lei de diretrizes orçamentárias orienta a elaboração da lei orçamentária e estabelece as metas e prioridades da Administração Pública. O direito financeiro, portanto, disciplina as finanças do Estado. Essas leis possibilitam um controle dos recursos públicos e racionalizam a sua aplicação.

As atividades chamadas de "controle" são executadas por todos os poderes e visam fiscalizar a execução do orçamento público, a sua legalidade, o cumprimento das metas e os contratos firmados. Os três poderes devem ter um sistema de controle interno, que no Poder Executivo Federal é feito pela Controladoria-Geral da União, além do controle externo prestado pelo Congresso com auxílio dos tribunais de contas. $\mathrm{O}$ direito orçamentário tem o intuito de disciplinar o orçamento público, instituindo metas e prioridades.

Historicamente, a Magna Carta, imposta a João Sem Terra, em 1215, pela nobreza e pela plebe, "outorgou ao Conselho dos Comuns o direito de votar os impostos e de determinar sua aplicação" ${ }^{\text {" }}$.

${ }^{39}$ CAMPOS, Dejalma de. Direito financeiro e orçamentário. 2. ed. São Paulo: Atlas, 2001. p. 59.

${ }^{40}$ CAMPOS, Dejalma de. Direito financeiro e orçamentário. 2. ed. São Paulo: Atlas, 2001. p. 72. 
Conforme Vieira ${ }^{41}$, o controle das contas públicas no Brasil remonta ao período do Brasil-Colônia. No Brasil-Império, em 15 de dezembro de 1830, foi instituído o primeiro orçamento para todo o Império, abrangendo 1831 e 1832 . Em 1831 foi criado o Tribunal do Tesouro Público Nacional. No Brasil-República, em 1890, foi criado o Tribunal de Contas, idealizado por Rui Barbosa, como Ministro da Fazenda, pelo Decreto $n^{\circ}$ 966/A, de 7 de novembro de 1890, mas somente em 1891 o Tribunal começou a funcionar, tendo depois sido chamado de Tribunal de Contas da União. O primeiro tribunal de contas foi criado na França e, pela sua eficiência, foi adotado em outros países, como Itália, França e Bélgica. O Brasil adota o modelo belga, ou seja, o Tribunal de Contas presta auxílio ao Congresso.

Os tribunais de contas têm competências e funções muito importantes para a economia nacional e para a seriedade das contas públicas, já que a própria Constituição de 1988, nos seus artigos 70 a 74, dispõe acerca da fiscalização contábil, financeira, orçamentária, operacional e patrimonial da União e das entidades da administração direta e indireta (autarquias, fundações, sociedades de economia mista e empresas públicas) $)^{42}$.

Pelo art. 71 da Carta Constitucional, compete ao Tribunal de Contas da União apreciar as contas prestadas anualmente pelo Presidente da República, jul-

${ }^{41}$ VIEIRA, Laércio Mendes. Controle estatal dos gastos públicos no Brasil: painel histórico e aspectos relevantes das instituições de controle. In: BUGARIN, Maurício Soares; VIEIRA, Laércio Mendes; GARCIA, Leice Maria (Org.). Controle dos gastos públicos no Brasil: instituições oficiais, controle social e um mecanismo para ampliar o envolvimento da sociedade. Rio de Janeiro: Konrad-Adenauer-Stiftung, 2003. p. 57-137.

${ }^{42}$ Para demonstrar a importância dos tribunais de contas, basta referir que perdas imensas de recursos públicos foram evitadas nos últimos anos por essa interferência do Tribunal. Um desses casos se deu em 1996, quando a corte apreciou o "processo de alienação da participação acionária da Petrobrás Química S.A. - Petroquisa - na Estireno do Nordeste S.A. - EDN. Naquela assentada, o Tribunal Pleno, acolhendo a proposta do Relator, Ministro Carlos Átila, decidiu sustar o leilão no qual ocorreria a venda da participação acionária da Petroquisa na EDN, por discordar dos estudos a partir dos quais foi fixado o preço mínimo da referida participação. Na mesma oportunidade, o Tribunal determinou ao BNDES que procedesse a uma reavaliação dessa participação, o que resultou em um novo preço mínimo no valor de 17 milhões de reais, preço este que superou em $80 \%$ o fixado anteriormente e motivou a sustação do leilão pelo TCU” OLIVEIRA, Arildo da Silva. Controle social: perspectivas para a fiscalização popular da administração pública no Brasil. In: TRIBUNAL DE CONTAS DA UNIÃO. Prêmio Serzedello Corrêa 2001 monografias vencedoras: perspectivas para o controle social e a transparência da administração. Brasília: Instituto Serzedello Corrêa, 2002. p. 143-207. 
gar as contas dos administradores e responsáveis por bens e valores públicos, apreciar a legalidade dos atos de admissão de pessoal, realizar inspeções e auditorias nos três poderes e nas entidades da administração pública indireta, fiscalizar as contas nacionais das empresas supranacionais de cujo capital social a União participe, fiscalizar a aplicação de recursos repassados pela União aos outros entes federativos, aplicar sanções nos caso de ilegalidade ou irregularidade de contas, além de multa proporcional, dar prazo para que o órgão responsável adote providências, caso seja constatada ilegalidade, sustar, se não atendido, a execução do ato impugnado, comunicando a decisão à Câmara dos Deputados e ao Senado Federal e representar ao Poder competente sobre irregularidades apuradas.

O art. 59 da Lei de Responsabilidade Fiscal, Lei Complementar n 101/2000, trouxe outras incumbências aos tribunais de contas, relativas à gestão fiscal, determinando um controle mais rígido das contas públicas, atendendo às exigências do princípio da economicidade, previsto no art. 70 do texto constitucional, e que foi consagrado pela jurisprudência dos tribunais de contas, e também à moralidade administrativa.

A atual Constituição trouxe grandes avanços no que concerne à fiscalização exercida pelos tribunais de contas, que passaram a ter assegurada a sua independência. Os tribunais de contas não são subordinados ao Congresso Nacional, não realizam atividades descentralizadas, têm competências privativas e indelegáveis, e, por conseguinte, são fundamentais na consolidação do processo democrático brasileiro. Assim como o Ministério Público, que adquiriu independência funcional, unidade e indivisibilidade, segundo o art. 127, $\$ 1^{\circ}$ da Constituição de 1988 , e autonomia funcional e administrativa, pelo $\$ 2^{\circ}$ do mesmo artigo, os tribunais de contas passaram a atuar com mais autoridade e independência, tendo inclusive o poder potestativo de afastar determinados administradores incursos em ilegalidades, sequestrar seus bens até definição das irregularidades, condenar ao recolhimento do débito apurado, formando título executivo judicial, aplicar multas, decretar indisponibilidade de bens necessários à satisfação do prejuízo por prazo não superior a um ano, realizar declaração de inabilitação, de 5 a 8 anos, para cargo em comissão ou função de confiança e declaração de inidoneidade do fraudador do processo licitatório, válido por até 5 anos.

A Lei Orgânica do Tribunal de Contas da União, Lei 8443/92, artigos 57 a 60, dispõe acerca das sanções que podem ser impostas pelo Tribunal em caso de 
descumprimento de exigências ou ilegalidade. Incumbe ainda ao Tribunal decidir consultas e decidir sobre representações em processos licitatórios, pela Lei n. ${ }^{\circ}$ 8443/92, exercer o controle de legalidade das declarações de bens de ocupantes de cargos públicos, pela Lei n. ${ }^{\circ} 8730 / 93$, processar e julgar infrações administrativas, pela Lei $n .^{\circ} 10.028 / 00$, entre outras atividades.

Tudo isso conduz ao conceito de accountability, que, segundo Silva ${ }^{43}$ equivale à ideia de "responsabilidade objetiva". No caso dos tribunais de contas, deve-se compreender o termo accountability como sinônimo de responsabilidade (política), ou seja, aqueles que atentam contra a ordem econômica fazem um dano a toda a sociedade, já que não é somente o Estado que tem um dever-poder em relação à sociedade, a sociedade também tem deveres. Há, portanto, uma responsabilidade objetiva dos gestores públicos com o que fazem com os recursos e bens públicos.

A instituição dos tribunais de contas como órgãos independentes do Poder Legislativo que auxiliam este Poder a elevar o nível de accountability - fiscalizando a lisura e a confiabilidade dos certames licitatórios, dos contratos e parcerias do governo com ONG'S, controlando a legalidade das obras públicas executadas conforme as previsões das leis orçamentárias - é fundamental, pois significa o marco de uma mudança, que traduz um progresso institucional do nosso país.

É preciso realçar a importância das funções fiscalizadora, consultiva, informativa, judicante, sancionadora, corretiva, normativa e de ouvidoria dos tribunais de contas. O Tribunal de Contas da União tem descoberto grandes irregularidades com a aplicação do dinheiro público que beiram ao absurdo e demonstra o quanto ainda estamos longe de um controle ideal dos gastos públicos, o que afeta inevitavelmente as políticas públicas no Brasil. O TCU detectou o desvio de perto de $\mathrm{R} \$ 1,5$ bilhão dos $\mathrm{R} \$ 3$ bilhões reservados pelo governo federal para organizações não-governamentais (ONGs) e organizações da sociedade civil de interesse público (Oscips). A respeito disso, informa o jornal O Estado de S. Paulo ${ }^{44}$ :

\footnotetext{
${ }^{43}$ SILVA, Francisco Carlos da Cruz. Controle social: reformando a administração para a sociedade. In: TRIBUNAL DE CONTAS DA UNIÃO. Prêmio Serzedello Corrêa 2001 monografias vencedoras: perspectivas para o controle social e a transparência da administração. Brasília: TCU, Instituto Serzedello Corrêa, 2002. p. 52.

${ }^{44}$ DOMINGOS, João. Quase metade da verba destinada a ONGs é desviada. O Estado de S. Paulo, São Paulo, 08 jul. 2007. Disponível em: <http://www.lostbrasil.com/viewtopic.php ? $\mathrm{p}=330119 \&$ sid=b68142eea2e03de0ba70a275fcdf2c68>. Acesso em: 30 jan. 2008.
} 
O governo federal destinou R\$ 3 bilhões a organizações não-governamentais (ONGs) e organizações da sociedade civil de interesse público (Oscips) no ano passado, segundo dados do Ministério do Planejamento. O valor corresponde a 1,29\% do Produto Interno Bruto (PIB). Do total, técnicos do governo, do Tribunal de Contas da União (TCU) e da Controladoria-Geral da União (CGU) calculam que quase a metade - perto de R \$ 1,5 bilhão - tenha sido desviada da finalidade original dos convênios ou encontrado algum ralo que represente a perda do dinheiro público.

Como exemplos disso, o Jornal da Tarde e o Estado vêm publicando desde a semana passada uma série de reportagens apontando irregularidades no Programa Brasil Alfabetizado, em que ONGs desviam recursos repassados pelo Ministério da Educação. Turmas fantasmas, professores sem receber e alfabetizadores cadastrados à revelia foram alguns dos problemas revelados. Umas dessas entidades, a Associação Amigos do Jardim Aracati, em São Paulo, até apareceu em propaganda do Brasil Alfabetizado na TV, mas não iniciou aulas até agora.

Os R\$ 3 bilhões destinados às ONGs significam um valor astronômico, se comparado aos $\mathrm{R} \$ 11,7$ bilhões (5,04\% do PIB) transferidos também em 2006 pela União aos 27 Estados e Distrito Federal e aos 5.561 municípios pelo Fundo de Participação dos Estados (FPE), Fundo de Participação dos Municípios (FPM), royalties pela exploração do petróleo e do gás natural, compensações financeiras devidas pela utilização de recursos hídricos e minerais e os valores pagos pela Itaipu Binacional.

Em 2002, o País tinha 22 mil ONGs; em 2006, esse número pulou para $260 \mathrm{mil}$; em 2007, calcula-se que tenham alcançado a casa das $300 \mathrm{mil}$, de acordo com informações do senador Heráclito Fortes (DEM-PI), autor do requerimento que cria a CPI das ONGs, a ser instalada em agosto. Num depoimento prestado ao Congresso, em maio, o general Maynard Marques Santa Rosa, secretário de Política, Estratégia e Assuntos Internacionais do Ministério da Defesa, informou que só na Amazônia atuam 100 mil ONGs, grande parte de origem estrangeira. Do total de 300 mil, somente 4,5 mil estão legalmente registradas no Ministério da Justiça. Toda essa enormidade de ONGs e Oscips é fiscalizada por apenas 12 funcionários da Justiça. Não é possível um controle efetivo das atividades delas.

Com esse extraordinário crescimento, não é à toa que em todo escândalo recente envolvendo repasse de verba da 
União e de outros órgãos públicos se encontre uma ONG ou Oscip. Houve desvio de R $\$ 50$ milhões no Banco de Brasília (BRB), descoberto pela Operação Aquarela, que resultou na renúncia do senador Joaquim Roriz (PMDB-DF) na semana que passou. Tem ONG por lá. Nesse caso do BRB, são três ONGs, todas ligadas a um dos principais suspeitos, Juarez Lopes Cançado. Uma é a Caminhar, que fornecia os cartões corporativos para saques na boca do caixa por conta de pagamento de pesquisas fraudadas, feitas em casa mesmo. Havia, ainda, o Projeto Conviver e o Instituto Êxito.

\section{REGRAS}

A situação é tão grave que o Ministério do Planejamento resolveu criar duras regras para a assinatura dos convênios. 'Desde o escândalo dos sanguessugas vimos que não dava para continuar do jeito atual. Então, fizemos várias reuniões com o Tribunal de Contas da União (TCU), que tem um trabalho de fiscalização muito bom a respeito dos convênios das ONGs, e com a Controladoria-Geral da União. O resultado foi a elaboração de um decreto com regras que visam a inibir as irregularidades, informou o ministro do Planejamento, Paulo Bernardo. (Descoberto em maio de 2006 pela Polícia Federal, o escândalo dos sanguessugas revelou uma rede de empresários, prefeitos, governadores e parlamentares que se apropriavam de verbas da União a partir da venda de ambulâncias superfaturadas.) 'É comum que a emenda do parlamentar ao Orçamento já venha com a indicação da ONG que vai prestar o serviço. O Executivo transforma-se apenas um repassador de verbas. É necessário que seja feita uma fiscalização eficiente, porque a proliferação de ONGs que se envolvem em irregularidades acaba por comprometer todas as outras', diz o ministro Marcos Bemquerer, do TCU, relator de um processo que fiscalizou 28 convênios com ONGs, encontrou irregularidades em 15 e descobriu que dos R \$ 150 milhões repassados, $\mathrm{R} \$ 82$ milhões foram desviados.

Nos convênios examinados, o TCU enumerou diversas irregularidades nas ONGs. Descobriu que entre os problemas estavam a falta de qualificação técnica e administrativa, inexperiência para receber recursos, metas vagas e prestação de contas confusas. Algumas foram criadas três meses antes da assinatura do convênio, sintoma de que seu objetivo era só pegar o dinheiro da União. Resultado: o desvio do dinheiro foi de $54,6 \%$, superior à metade dos recursos empregados. 
A Lei n. ${ }^{\circ}$ 9790/99 instituiu as organizações da sociedade civil de interesse público (Oscips), associações civis que podem receber bens e recursos públicos para atuação em áreas de interesse público, por meio de parcerias firmadas, visando, entre outros objetivos, pelo art. $3^{\circ}$, inciso XI - à promoção da ética, da paz, da cidadania, dos direitos humanos, da democracia e de outros valores universais. Diz Vieira ${ }^{45}$ que " $[. .$.$] essas entidades não têm obrigatoriedade de prestar contas ao con-$ trole externo ou interno regularmente, mas estes têm a prerrogativa de fiscalizá-las quando entenderem conveniente, já que se trata de recursos públicos".

O desvio de R \$ 1,5 bilhão reservado pelo governo federal para essas entidades certamente tem como causa a ausência de um controle mais eficiente. É preciso a instituição de um controle mais eficiente. Atualmente, após a prestação de serviços ou realização de obras, cada ONG tem que prestar contas ao Ministério respectivo, que deve verificar se a verba foi bem utilizada ${ }^{46}$, mas ainda existem sérios problemas na fiscalização dos convênios. Segundo o Min. do TCU, Marcos Bemquerer, foram encontradas as seguintes irregularidades nos convênios entre ONGs e Ministérios em 2006: 1) problemas no critério de escolha das entidades; 2) falta de avaliação adequada dos projetos; 3 ) necessidade de maior fiscalização; 4) superfaturamento; e 5) irregularidades nos processos de licitação ${ }^{47}$. Junte-se a isso o fato de não necessitarem realizar licitação. Dada a magnitude do desperdício de recursos públicos (mais de $\mathrm{R} \$ 1$ bilhão e mais de 1\% do PIB!), não é compreensível a precariedade do controle exercido, ainda mais quando tais entidades se tornam meios para que particulares se locupletem de receitas públicas que têm (deveriam ter) finalidades sociais. O aumento de mais de $1000 \%$ no número de ONGs existentes entre 2002 e 2006 (de 22 mil para 360 mil) não é casual, pois elas se torna-

${ }^{45}$ VIEIRA, Laércio Mendes. Controle estatal dos gastos públicos no Brasil: painel histórico e aspectos relevantes das instituições de controle. In: BUGARIN, Maurício Soares; VIEIRA, Laércio Mendes; GARCIA, Leice Maria (Org.). Controle dos gastos públicos no Brasil: instituições oficiais, controle social e um mecanismo para ampliar o envolvimento da sociedade. Rio de Janeiro: Konrad-Adenauer-Stiftung, 2003. p. 71.

${ }^{46}$ ASSOCIAÇÃO BRASILEIRA DE ASSOCIAÇÕES NÃO-GOVERNAMENTAIS. Parte III - Sustentabilidade e autonomia. Disponível em: <http://www2.abong.org.br/final/livre. php?cd_materia=18036> Acesso em: 30 maio 2010.

${ }^{47}$ DIREITO DO ESTADO. Fiscalização de convênios com ONGs não é "satisfatório", admite ministro do TCU. 2007. Disponível em: <http://www.direitodoestado.com/noticias/noticias_detail.asp?cod=4878>. Acesso em: 13 maio 2009. 
ram, para muitos, um meio de praticar ilícitos ${ }^{48}$. Entendemos que muitas dessas entidades realizam dignamente os fins para que foram criadas, mas outra parcela considerável não serve senão para acobertar interesses pessoais ou para explorar o erário público. A respeito da importância das ONGs nos cenários nacional e internacional, discorrem Morais e Streck ${ }^{49}$ :

Outro agente fundamental neste processo de transformação - de eclipse, para alguns - da noção de soberania são as Organizações Não-Governamentais (ONGs). Estas entidades, que podem ser enquadradas em um espaço intermediário entre o público, representado pelos organismos internacionais, e o privado, representado pelas empresas transnacionais, atuam em setores variados, tais como: ecologia (Greenpeace), direitos humanos (Anistia Internacional), saúde (Médicos Sem Fronteiras), etc. O papel das mesmas vem-se aprofundando, sendo, nos dias que correm, muitas vezes imprescindíveis para que certos Estados tenham acesso a programas internacionais de ajuda, possam ser admitidos em determinados acontecimentos da ordem internacional, etc. Tais vínculos, incongruentes com a ideia de poder soberano, são uma realidade da contemporaneidade onde os relatórios destas entidades podem significar reconhecimento ou repúdio em nível internacional, com reflexos inexoráveis na ordem interna de tais países, em especial naqueles que dependem da "ajuda" econômica internacional.

Mello $^{50}$ já alertava, referindo-se às organizações sociais, que "Na lei disciplinadora das organizações sociais chamam atenção alguns pontos nos quais se patenteiam inconstitucionalidades verdadeiramente aberrantes". Essas entidades privadas, qualificadas pelo ministro como sem fins lucrativos, travando "contrato de gestão", podem receber bens públicos em permissão de uso e sem licitação, inclusive imóveis, pelo art. $12, \$ 3^{\circ}$ da Lei n. ${ }^{\circ}$ 9637/98. Podem ainda receber recursos orçamentários (art. 12) e servidores públicos pagos pelo erário público (art. 14). Para que essas entidades recebam bens, basta a concordância do ministro da área.

${ }^{48}$ DOMINGOS, João. Quase metade da verba destinada a ONGs é desviada O Estado de $S$. Paulo, São Paulo, 08 jul. 2007. Disponível em: <http://www.lostbrasil.com/viewtopic.php $? \mathrm{p}=330119 \&$ sid=b68142eea2e03de0ba70a275fcdf2c68>. Acesso em: 30 jan. 2008.

${ }^{49}$ MORAIS, José Luis Bolzan de; STRECK, Lenio Luiz. Ciência política e teoria geral do Estado. 4. ed. Porto Alegre: Livraria do Advogado, 2004. p. 133.

${ }^{50}$ MELLO, Celso Antônio Bandeira de. Curso de direito administrativo. 18. ed. São Paulo: Malheiros, 2005. p. 223. 
Isso fere claramente a finalidade do art. 37, XXI, que exige o procedimento licitatório e o art. $5^{\circ}$, caput da Constituição, que consagra o princípio da isonomia.

Nesse ponto, Mello ${ }^{51}$ afirma que para receber bens e recursos orçamentários, seria preciso a demonstração da habilitação técnica ou econômico-financeira, ou seja, a lei outorga uma "discricionariedade literalmente inconcebível, até mesmo escandalosa, por sua desmedida amplitude, e que permitirá favorecimentos de toda espécie". Fere, portanto, ao princípio da isonomia conceder bens públicos aos particulares sem um regular processo licitatório, considerando-se que a máxima da igualdade pressupõe tratamento desigual aos desiguais e que o critério de desigualdade não pode ser arbitrário.

Isso demonstra que essas entidades, incluindo Oscips, ONGs e organizações sociais, merecem um controle mais efetivo. As Oscips, por exemplo, têm objeto mais amplo que as organizações sociais, como benemerência social. É espantoso que entidades de benemerência social e de políticas públicas, sejam usadas como "laranjas" de esquemas fraudulentos. Veja-se como exemplo disso a conclusão do Min. do TCU, Marcos Bemquerer, de que os convênios entre ministérios e organizações não-governamentais (ONGs) são feitos muitas vezes para burlar licitações e concursos públicos, como o caso de compras que poderiam ter sido feitas pelos ministérios e que foram repassadas para essas entidades. ${ }^{52}$

Dado que o Tribunal de Contas tem a competência de julgar as contas dos responsáveis por bens, dinheiros e valores da Administração Pública (art. 71, II da Constituição de 1988), é preciso fortalecer o controle nessa instituição. Na própria criação dessas entidades, o Poder Público deveria verificar se essas atendem aos requisitos legais, entre os quais estão as necessárias habilitações técnicas e econômicas. Além disso, é fundamental uma ação conjunta do Ministério Público, com a ação penal pública e da sociedade, pois o art. $1^{\circ}$ da Lei 4717/65 confere ao cidadão legitimidade ativa para pleitear a anulação de atos lesivos ao patrimônio dos entes federativos ou da administração pública indireta, e o art. 11 responsabiliza aqueles que usam indevidamente bens ou recursos públicos, por meio da ação popular.

${ }^{51}$ MELLO, Celso Antônio Bandeira de. Curso de direito administrativo. 18. ed. São Paulo: Malheiros, 2005. p. 224.

52 DIREITO DO ESTADO. Fiscalização de convênios com ONGs não é "satisfatório", admite ministro do TCU. 2007. Disponível em: <http://www.direitodoestado.com/noticias/noticias_detail.asp?.cod=4878>. Acesso em: 13 maio 2009. 


\section{A baixa eficácia das condenações dos tribunais de contas}

Um problema que afeta os Tribunais de Contas é o da baixa eficácia das suas condenações. Oliveira ${ }^{53}$ afirma que: "Segundo o ex-ministro do TCU Bento Bugarin, menos de $2 \%$ do total das condenações ocorridas no âmbito daquela corte retornam aos cofres públicos". É fundamental notarmos que isso se deve, em grande parte, ao fato de que o arresto cautelar de bens, previsto no art. 44 da Lei Orgânica do TCU, "[...] é uma medida que a Corte tem usado com grande parcimônia - para não dizer abstinência mesmo" ${ }^{54}$. A decisão que tornou indisponíveis os bens dos envolvidos no desvio de R\$ 169,5 milhões no TRT de São Paulo significa uma mudança de mentalidade.

As funções fiscalizadora, consultiva, informativa, judicante, sancionadora, corretiva, normativa e de ouvidoria são próprias do TCU, mas há uma preponderância da função fiscalizadora, de apreciação da legalidade das contas e gastos públicos, sendo que as funções sancionadora (de aplicação de sanções) e judicante (julgamento das contas dos administradores, dos gestores públicos, dos contratos e das obras públicas) devem ser aprimoradas.

É essencial a intensificação do uso do arresto dos bens daqueles que estejam envolvidos em indícios de irregularidades, sob pena de perda do patrimônio passível de ser executado judicialmente. A fase executória é central e requer uma profunda atenção dos ministros do TCU, porque apesar da Corte não ter competência jurisdicional, a sua função judicante impõe um dever referentemente à futura execução judicial. A ideologia do TCU sempre foi voltada para um controle formal de legalidade das contas públicas, estruturada em auditorias e cálculos contábeis, visando à deteç̧ão de ilicitudes, mas tão fundamental quanto à função fiscalizadora é a função judicante, e essa ficará sempre prejudicada quando os bens necessários não forem arrestados, possibilitando a evasão do patrimônio. O grau

\footnotetext{
${ }^{53}$ OLIVEIRA, Arildo da Silva. Controle social: perspectivas para a fiscalização popular da administração pública no Brasil. In: TRIBUNAL DE CONTAS DA UNIÃO. Prêmio Serzedello Corrêa 2001 monografias vencedoras: perspectivas para o controle social e a transparência da administração. Brasília: Instituto Serzedello Corrêa, 2002. p. 183.

${ }^{54}$ OLIVEIRA, Arildo da Silva. Controle social: perspectivas para a fiscalização popular da administração pública no Brasil. In: TRIBUNAL DE CONTAS DA UNIÃO. Prêmio Serzedello Corrêa 2001 monografias vencedoras: perspectivas para o controle social e a transparência da administração. Brasília: Instituto Serzedello Corrêa, 2002. p. 184.
} 
de accountability (responsabilização) daqueles que atentam contra a ordem econômica também é prejudicado pela morosidade e pela burocracia ${ }^{55}$ Enquanto a perspectiva burocrática centra-se no processo, em normas rígidas e formais, em uma hierarquia institucional, um controle severo, uma ausência de flexibilização e na subordinação, uma perspectiva gerencialista é enfocada no resultado, no fim, e, nesse sentido, é mais flexível. As reformas administrativas do Estado têm se pautado, em linhas gerais, por uma burocratização acentuada. A burocracia conduz a um controle preventivo que reage ao nepotismo e à corrupção. Diz Pereira ${ }^{56}$ :

A administração pública gerencial emergiu na segunda metade deste século como resposta à crise do Estado, como modo de enfrentar a crise fiscal, como estratégia para reduzir o custo e tornar mais eficiente a administração dos imensos serviços que cabiam ao Estado e como instrumento de proteção do patrimônio público contra os interesses do rent-seeking ou da corrupção aberta.

Vieira $^{57}$ afirma:

A corte entende que deve julgar todos os processos de contas conforme o mesmo rito processual, admitindo poucas exceções, como por exemplo, as tomadas de contas especiais referentes a débitos até 6.000 UFIR (Unidades Fiscais de

\footnotetext{
${ }^{55}$ Enquanto a perspectiva burocrática centra-se no processo, em normas rígidas e formais, em uma hierarquia institucional, um controle rígido, uma ausência de flexibilização e na subordinação, uma perspectiva gerencialista é enfocada no resultado, no fim e, nesse sentido, é mais flexível. As reformas administrativas do Estado têm se pautado, em linhas gerais, por uma burocratização acentuada. A burocracia conduz a um controle preventivo, que reage ao nepotismo e à corrupção. Diz Pereira: "A administração pública gerencial emergiu na segunda metade deste século como resposta à crise do Estado, como modo de enfrentar a crise fiscal, como estratégia para reduzir o custo e tornar mais eficiente a administração dos imensos serviços que cabiam ao Estado e como instrumento de proteção do patrimônio público contra os interesses do rent-seeking ou da corrupção aberta". Cf. PEREIRA, Luiz Carlos Bresser. Da administração pública burocrática à gerencial. In: PEREIRA, Luiz Carlos Bresser; SPINK, Peter Kevin (Org.). Reforma do Estado e administração pública gerencial. 5. ed. Rio de Janeiro: FGV, 2003. p. 237-270, p. 28.

${ }^{56}$ PEREIRA, Luiz Carlos Bresser. Da administração pública burocrática à gerencial. In: PEREIRA, Luiz Carlos Bresser; SPINK, Peter Kevin (Org.). Reforma do Estado e administração pública gerencial. 5. ed. Rio de Janeiro: FGV, 2003. p. 237-270.

${ }^{57}$ VIEIRA, Laércio Mendes. Controle estatal dos gastos públicos no Brasil: painel histórico e aspectos relevantes das instituições de controle. In: BUGARIN, Maurício Soares; VIEIRA, Laércio Mendes; GARCIA, Leice Maria (Org.). Controle dos gastos públicos no Brasil: instituições oficiais, controle social e um mecanismo para ampliar o envolvimento da sociedade. Rio de Janeiro: Konrad-Adenauer-Stiftung, 2003. p. 86.
} 
Referência), que não precisam ser enviadas imediatamente, mas apensadas ao processo regular de contas da unidade.

Tudo isso conduz a uma burocratização cada vez maior, porque os processos deveriam seguir ritos apropriados, com um grau de cognição pleno quando fossem maiores os indícios de irregularidades, e com uma cognição sumária nos casos necessários. Têm sido interpostos, ainda, recursos com a intenção de suspender os efeitos da lista de gestores tornados inelegíveis pelo TCU durante o período eleitoral. Tudo isto contribui para a impunidade, porque há uma manipulação do sistema recursal em prol dos gestores públicos. É preciso reconsiderar as funções clássicas do TCU e buscar a implementação de uma mudança substancial na Corte, principalmente quanto ao problema da efetividade das condenações.

\section{Algumas sugestões para o aprimoramento do controle}

A partir dessas informações, pretende-se elencar algumas sugestões que possibilitarão um incremento do controle, tendo sempre em vista que, conforme bem explanou o Ministro do Tribunal de Contas da União, Min. Marcos Bemque$\operatorname{rer}^{58}$, quem tem a obrigação, em primeiro lugar, de fiscalizar a destinação das verbas destinadas às organizações é o órgão que firma o convênio, ou seja, os repasses feitos pelo governo federal devem ser controlados pelos Ministérios. O TCU atua subsidiariamente, ou seja, em caso de denúncias e de indício de irregularidades. Podemos elencar algumas possibilidades que auxiliariam na perspectiva de fiscalização:

1. Vieira ${ }^{59}$ afirma que

[...] essas entidades não têm obrigatoriedade de prestar contas ao controle externo ou interno regularmente, mas estes têm a prerrogativa de fiscalizá-las quando

58 DIREITO DO ESTADO. Fiscalização de convênios com ONGs não é "satisfatório", admite ministro do TCU. 2007. Disponível em: <http://www.direitodoestado.com/noticias/noticias_detail.asp? cod=4878>. Acesso em: 13 maio 2009.

${ }^{59}$ VIEIRA, Laércio Mendes. Controle estatal dos gastos públicos no Brasil: painel histórico e aspectos relevantes das instituições de controle. In: BUGARIN, Maurício Soares; VIEIRA, Laércio Mendes; GARCIA, Leice Maria (Org.). Controle dos gastos públicos no Brasil: instituições oficiais, controle social e um mecanismo para ampliar o envolvimento da sociedade. Rio de Janeiro: Konrad-Adenauer-Stiftung, 2003. p. 71. 
entender conveniente, já que se trata de recursos públicos”. Entendemos que, dada a magnitude de verbas desviadas, deveria haver maior rigor na prestação de contas. Alerta o relator da CPI das ONGs, senador Raimundo Colombo (DEM-SC), que apesar de as ONGs deverem prestar contas dos repasses do governo, pouco se sabe do que é feito com os recursos destinados a elas - a fiscalização é precária. Além disso, o governo pretende publicar um decreto que tornará mais rigorosa e transparente a fiscalização sobre o uso dos recursos públicos ${ }^{60}$.

2. Na própria criação dessas entidades, o Poder Público deveria verificar de forma mais rígida se elas atendem aos requisitos legais, entre os quais estão as necessárias habilitações técnicas e econômicas, possibilitando então um maior controle acerca da criação de tais entidades e definição de critérios objetivos e técnicos aos convênios.

3. Além disso, é fundamental uma ação conjunta do Ministério Público, com a ação penal pública, e da sociedade, pois o art. $1^{\circ}$ da 4717/65 confere ao cidadão legitimidade ativa para pleitear a anulação de atos lesivos ao patrimônio dos entes federativos ou da administração pública indireta, e o art. 11 responsabiliza aqueles que usam indevidamente bens ou recursos públicos, por meio da ação popular.

4. O aprimoramento da perspectiva judicante e sancionadora dos Tribunais de Contas; a utilização de ritos processuais adequados; a intensificação do uso do arresto; o aprimoramento da perspectiva gerencialista.

O Min. Bemquerer ainda sugere que os repasses financeiros constem na internet, possibilitando uma maior transparência (efetivação do princípio da transparência dos atos da Administração Pública) ${ }^{61}$.

${ }^{60}$ ASSOCIAÇÃO BRASILEIRA DE ASSOCIAÇÕES NÃO-GOVERNAMENTAIS. Parte III - Sustentabilidade e autonomia. Disponível em: <http://www2.abong.org.br/final/livre. php?cd_materia=18036> Acesso em: 30 maio 2010.

61 DIREITO DO ESTADO. Fiscalização de convênios com ONGs não é "satisfatório", admite ministro do TCU. 2007. Disponível em: <http://www.direitodoestado.com/noticias/noticias_detail.asp?cod=4878>. Acesso em: 13 maio 2009. 


\section{Considerações finais}

Este trabalho buscou perspectivas para o controle, tanto por parte do governo quanto pelos tribunais de contas, especialmente o TCU, diante do desperdício e desvio de verbas públicas por entidades que visam implementar finalidades e políticas públicas. É preciso aumentar a eficiência dos tribunais de contas, notadamente quanto ao problema da eficácia das suas condenações e o controle por parte do governo. O tema das políticas públicas é correlativo aos mecanismos de controle que possibilitam que os recursos destinados não sejam manipulados indevidamente, sob pena do fracasso na implementação das políticas públicas.

O controle dos gastos públicos e a instituição de mecanismos de combate ao desperdício de recursos públicos são funções primordiais dos tribunais de contas. A burocracia, o formalismo processual, a inefetividade das decisões condenatórias e a necessidade da intensificação do controle sobre ONGs e Oscips são questões centrais que precisam ser enfrentadas, visando à ampliação do controle externo e à maior lisura nas contas públicas no Brasil.

O enfraquecimento da repressão aos crimes econômicos estimula a malversação dos recursos públicos. O que é visível é que a impunidade conferida aos crimes econômicos inviabiliza a necessária proteção penal de bens jurídicos fundamentais. Isso representa uma porta aberta para o desperdício, além da má aplicação e da falta de racionalização das despesas públicas.

A implementação de um Estado Social e Democrático de Direito perpassa um conjunto de medidas que fortaleça a seriedade das despesas públicas, racionalizando a sua aplicação, por meio da aplicação irrestrita das leis orçamentárias, do fortalecimento das instituições de controle - notadamente dos tribunais de contas. O certo é que tal entidade tem um papel fundamental na implementação de políticas públicas em diversas áreas, mas o uso adequado dos recursos econômicos é conditio sine qua non para que tais propostas sejam concretizadas, o que só se dará mediante uma maior fiscalização daquelas entidades que efetivamente estiverem agindo contra o Estado de Direito e o interesse público.

A partir disso, o trabalho buscou trazer algumas sugestões para o aprimoramento do controle, porque a lisura dos convênios com tais entidades é 
condição indispensável para a tutela das políticas públicas no Estado Democrático de Direito. É o que se espera de um Estado que lide com seriedade com as políticas públicas.

\section{Perspectives for the protection of the public policies in the democratic state of law: the control effectiveness in the deviation of public budgets bu NOGs AND 'OSCIPs'}

\section{Abstract}

The objective of this work is to discuss some difficulties of the control managed by the courts of account and the government, so as to observe the way these institutions deal with the inspection of federal income. Having as principle the fact that public policies are essential to the improvement and constitution of a social state, it was carried out an analysis about the control systems in the application of public resources by NGOs and Oscips. Afterwards, suggestions aiming at the improvement of public resources' control were offered. This way, it is clear that courts of account have an important role in the implementation of public policies in different areas, since the inspection of income by these institutions can increase the public transparency. Moreover, the rationalization of public expenses and the measures against loss depend on institutional action and empowerment of courts of account for a better application of resources in public policies.

Keywords: Economic order. External control. Public expenses. Democratic State of public policies.

\section{Referências}

ASSOCIAÇÃO BRASILEIRA DE ASSOCIAÇÕES NÃO-GOVERNAMENTAIS. Parte III - Sustentabilidade e autonomia. Disponível em: $<$ http://www2.abong.org. br/final/livre.php?cd_materia=18036> Acesso em: 30 maio 2010.

BALEEIRO, Aliomar; DERZI, Misabel Abreu Machado. Direito tributário brasileiro. 11. ed. Rio de Janeiro: Forense, 2005.

BONAVIDES, Paulo. Do estado liberal ao social. São Paulo: Malheiros, 2004. 
BRASIL. Constituição (1988). Constituição da República Federativa do Brasil. Disponível em: <http://www.planalto.gov.br/ccivil_03/Constituicao/Constituiçao. htm>. Acesso em: 7 jun. 2009.

BRASIL. Decreto-lei 2.848, de 7 de dezembro de 1940. Brasília, 1940. Disponível em: <_http://www.planalto.gov.br/CCIVIL/Decreto-Lei/ Del2848.htm>. Acesso em: 06 jun. 2009.

BRASIL. Lei complementar 101, de 4 de maio de 2000. Estabelece normas de finanças públicas voltadas para a responsabilidade na gestão fiscal e dá outras providências. Brasília, 2000. Disponível em: <http://www.planalto.gov.br/ccivil_03/Leis/LCP/ Lcp101.htm> Acesso em: 7 jun. 2009.

BRASIL. Lei 4.717, de 29 de junho 1965. Regula a ação popular. Brasília, 1965. Disponível em: <http://www.planalto.gov.br/ccivil_03/Leis/ L4717.htm>. Acesso em: 7 jun. 2009.

BRASIL. Lei 8.443/92, de 16 de julho de 1992. Dispõe sobre a lei orgânica do tribunal de contas da união e dá outras providências. Brasília, 1992. Disponível em: <http://www.planalto.gov.br/ccivil_03/Leis/L8443.htm>. Acesso em: 7 jun. 2009.

BRASIL. Lei 8.730, de 10 de Novembro de 1993. Estabelece a obrigatoriedade da declaração de bens e rendas para o exercício de cargos, empregos e funções nos poderes executivo, legislativo e judiciário, e dá outras providências. Brasília, 1993. Disponível em: <http://www.planalto.gov.br/ccivil_03/Leis/L8730.htm>. Acesso em: 7 jun. 2009.

BRASIL. Lei 8.883/94, de 8 de junho de 1994. Altera dispositivos da lei No 8.666, de 21 de junho de 1993, que regulamenta o art. 37, inciso XXI, da Constituição Federal, institui normas para licitações e dá outras providências. Brasília, 1994. Disponível em: <http://www.planalto.gov.br/ccivil_03/Leis/ L8883.htm>. Acesso em: 07 jun. 2009.

BRASIL. Lei 9.637, de 15 de Maio de 1998. Dispõe sobre a qualificação de entidades como organizações sociais, a criação do programa nacional de publicização, a extinção dos órgãos e entidades que menciona e a absorção de suas atividades por organizações sociais, e dá outras providências. Brasília, 1998. Disponível em: <http://www.planalto.gov.br/ccivil_03/Leis/ L9637.htm> Acesso em: 7 jun. 2009.

BRASIL. Lei 9.648, de 27 de Maio de 1998. Altera dispositivos das leis no 3.890a, de 25 de abril de 1961, no 8.666, de 21 de junho de 1993, no 8.987, de 13 de fevereiro de 1995, no 9.074, de 7 de julho de 1995, no 9.427, de 26 de dezembro de 
1996, e autoriza o poder executivo a promover a reestruturação da centrais elétricas brasileiras - Eletrobrás e de suas subsidiárias e dá outras providências. Brasília, 1998. Disponível em: <http://www.planalto.gov.br/ccivil_03/Leis/L9648cons. htm>. Acesso em: 7 jun. 2009.

BRASIL. Lei 9.790, de 23 de Março de 1999. Dispõe sobre a qualificação de pessoas jurídicas de direito privado, sem fins lucrativos, como organizações da sociedade civil de interesse público, institui e disciplina o termo de parceria, e dá outras providências. Brasília, 1999. Disponível em: <http://www.planalto.gov.br/ ccivil_03/Leis/L9790.htm>. Acesso em: 7 jun. 2009.

BRASIL. Lei 10.028, de 19 de Outubro de 2000. Altera o decreto-lei no 2.848, de 7 de dezembro de 1940 - código penal, a lei no 1.079, de 10 de abril de 1950, e o decreto-lei no 201, de 27 de fevereiro de 1967. Brasília, 2000. Disponível em: <http://www.planalto.gov.br/ccivil_03/Leis/L10028.htm>. Acesso em: 7 jun. 2009.

CAMPOS, Dejalma de. Direito financeiro e orçamentário. 2. ed. São Paulo: Atlas, 2001.

CHIMENTI, Ricardo Cunha; et al. Curso de direito constitucional. 4. ed. São Paulo: Saraiva, 2007.

COPETTI, André. Direito penal e estado democrático de direito. Porto Alegre: Livraria do Advogado, 2000.

CUNHA, Fernando Whitaker da. Teoria geral do Estado: introdução ao direito constitucional. Rio de Janeiro: Freitas bastos, 1990.

DIREITO DO ESTADO. Fiscalização de convênios com ONGs não é "satisfatório", admite ministro do TCU. 2007. Disponível em: <http://www.direitodoestado.com/ noticias/noticias_detail.asp?cod=4878>. Acesso em: 13 maio 2009.

DOMINGOS, João. Quase metade da verba destinada a ONGs é desviada. O Estado de S. Paulo, São Paulo, 08 jul. 2007. Disponível em: <http://www.lostbrasil.com/ viewtopic.php? $\mathrm{p}=330119 \&$ sid $=\mathrm{b} 68142 \mathrm{eea} 2 \mathrm{e} 03 \mathrm{de} 0 \mathrm{ba70a} 275 \mathrm{fcdf} 2 \mathrm{c} 68>$. Acesso em: 30 jan. 2008.

FARIA, José Eduardo. O direito na economia globalizada. São Paulo: Malheiros, 2004.

MELlO, Celso Antônio Bandeira de. Curso de direito administrativo. 18. ed. São Paulo: Malheiros, 2005. 
MORAIS, José Luis Bolzan de; STRECK, Lenio Luiz. Ciência política e teoria geral do Estado. 4. ed. Porto Alegre: Livraria do Advogado, 2004.

OLIVEIRA, Arildo da Silva. Controle social: perspectivas para a fiscalização popular da administração pública no Brasil. In: TRIBUNAL DE CONTAS DA UNIÃO. Prêmio Serzedello Corrêa 2001 monografias vencedoras: perspectivas para o controle social e a transparência da administração. Brasília: Instituto Serzedello Corrêa, 2002. p. 143-207.

PEREIRA, Luiz Carlos Bresser. Da administração pública burocrática à gerencial. In: PEREIRA, Luiz Carlos Bresser; SPINK, Peter Kevin (Org.). Reforma do Estado e administração pública gerencial. 5. ed. Rio de Janeiro: FGV, 2003. p. 237-270.

SARLET, Ingo. Direitos fundamentais sociais e proibição de retrocesso: algumas notas sobre o desafio da sobrevivência dos direitos sociais num contexto de crise. Revista do Instituto de Hermenêutica Jurídica, Porto Alegre, v. 1, n. 2, p. 217-242, anual. 2004.

SCHILLING, Voltaire. As grandes correntes do pensamento. 2. ed. Porto Alegre: AGE, 1999.

SILVA, José Afonso da. Aplicabilidade das normas constitucionais. 6. ed. São Paulo: Malheiros, 2004.

SILVA, José Afonso da. Curso de direito constitucional positivo. 24. ed. São Paulo: Malheiros, 2005.

SILVA, Francisco Carlos da Cruz. Controle social: reformando a administração para a sociedade. In: TRIBUNAL DE CONTAS DA UNIÃO. Prêmio Serzedello Corrêa 2001 monografias vencedoras: perspectivas para o controle social e a transparência da administração. Brasília: TCU, Instituto Serzedello Corrêa, 2002. p. 21-72.

VIEIRA, Laércio Mendes. Controle estatal dos gastos públicos no Brasil: painel histórico e aspectos relevantes das instituições de controle. In: BUGARIN, Maurício Soares; VIEIRA, Laércio Mendes; GARCIA, Leice Maria (Org.). Controle dos gastos públicos no Brasil: instituições oficiais, controle social e um mecanismo para ampliar o envolvimento da sociedade. Rio de Janeiro: Konrad-AdenauerStiftung, 2003. 


\title{
Constitucionalismo $x$ democracia: o multiculturalismo e as comunidades tradicionais ${ }^{1}$
}

\author{
Kerlay Lizane Arbos ${ }^{2}$ \\ Carlos Frederico Marés de Souza Filho ${ }^{3}$
}

\section{Resumo}

Este trabalho analisa o surgimento do multiculturalismo como um desafio para as democracias liberais apoiadas na ideia de igualdade. Busca-se um multiculturalismo democrático como política capaz de reconhecer a singularidade de cada cultura, ampliando o diálogo, o respeito e aliando-se aos princípios constitucionais de dignidade e respeito à diversidade cultural. Em que pese o multiculturalismo abarcar diversas minorias; o presente estudo se restringirá à análise da questão a partir da ótica das comunidades tradicionais, estas, por sua vez, reivindicam do Estado e da sociedade o reconhecimento de seus direitos. A emergência dessas reivindicações de diversos grupos culturalmente diferenciados surge em razão de uma perspectiva universalista insuficiente e incapaz de contemplar as diferentes identidades sociais e realizar um dos fundamentos da democracia que é o princípio de igualdade para todos. Esses grupos lutam pelo direito de ser diferente, e recusam o ideal do mundo capitalista e burocrático, que impõe padrões de comportamento e valores essencialmente discriminatórios e excludentes. A nossa sociedade é possuidora de vasta diversidade cultural, e a diferença apresenta-se como um componente estrutural da vida social que precisa ser novamente harmonizado com o aspecto multicultural dos povos. Conclui-se, portanto, que a democracia, em que pese diversos problemas existentes, é ainda o campo no qual podem ser sustentadas ideias multiculturais, já que é um espaço em que se permite o debate e, consequentemente, o aperfeiçoamento de ideais. $\mathrm{O}$ valor e a originalidade do trabalho estão relacionados à proposta de

\footnotetext{
1 Este artigo está cadastrado no Digital Object Identifier System sob o número doi: 10.5102/ prismas.2010.07.1.03 Disponível em: <www.publicaçõesacadêmicas.uniceub.br >.

2 Advogada, Especialista em Gestão Ambiental pela UFPR, Mestranda do Programa de Pós-graduação em Direito Econômico e Socioambiental da PUCPR, Bolsista CAPES.

3 Procurador do Estado do Paraná, Mestre e Doutor pela UFPR, Professor de graduação e Pós-graduação da PUCPR.
} 
radicalizar a democracia, enfatizando-se a necessidade da incorporação das diferenças pelos sistemas democráticos atuais, bem como a necessidade de desmistificar uma pretensa homogeneidade cultural construída.

Palavras-chave: Constitucionalismo. Democracia. Comunidades tradicionais. Multiculturalismo.

\section{Introdução}

O objetivo central deste estudo é ressaltar a importância do multiculturalismo e da diversidade cultural dos grupos humanos, a exemplo das comunidades tradicionais, bem como a necessidade de que esses grupos sejam respeitados e reconhecidos dentro do espaço democrático, o local propício para se sustentar ideias multiculturais e estabelecer debates que permitam o seu contínuo aperfeiçoamento.

Em um primeiro momento, analisam-se os postulados de constitucionalismo e democracia, e a tensão existente entre estes diante da questão pluralista das comunidades tradicionais.

Após, busca-se fornecer noções sobre multiculturalismo e a importância do reconhecimento da diversidade cultural, além da adoção tímida de uma postura multicultural e pluralista pela Constituição Federal de 1988. Neste ínterim, é válido ressaltar que não será analisada qualquer abordagem multicultural específica, apenas serão levantadas questões gerais importantes para incentivar o debate multicultural dentro do cenário democrático.

Os grupos culturalmente diferenciados ou comunidades tradicionais clamam, ao longo dos tempos, pelo reconhecimento de sua cultura singular. Esse desejo de serem reconhecidos, enquanto povos diferenciados não se baseia em políticas igualitárias, assimilacionistas ou integracionistas, mas sim em políticas de reconhecimento das diferenças que propiciarão a construção de um patrimônio histórico e cultural e a formação de uma identidade nacional.

Em diversos espaços, há lutas por direitos de reconhecimento, de pertencimento a uma determinada cultura ou grupo social. São essas lutas que conduzem as sociedades humanas a encontrarem uma forma específica de ser, o que confere significado à vida e às diferenças culturais. 
A diferença cultural inerente a cada grupo social espalhado pela superfície do planeta faz surgir o que se denomina de multiculturalismo. No entanto, tal conceito ainda é obscuro, uma vez que, por muito tempo, apresentou uma faceta apenas descritiva de como os antepassados se adaptaram às condições ambientais.

Hoje as transformações pelas quais a humanidade passa são rápidas e profundas, é comum se perderem as referências e valores do passado por conta de tais transformações, o que torna o presente cada vez mais consumista e predatório, e isso atinge diretamente o pensamento e o respeito à diversidade cultural e biológica.

Os valores da modernidade, tais como liberdade, igualdade, justiça etc. são cada vez mais díspares para pessoas ou grupos sociais diferentes. As consequências provenientes dos processos de formação homogeinizadora da sociedade, pautados sempre na ideia falaciosa de igualdade entre os diferentes indivíduos, acarretaram a exclusão de vários grupos coletivos da sociedade, bem como o não reconhecimento de reivindicações culturais expostas por eles.

Dessa forma, o multiculturalismo surge como um desafio aos governos atuais tão fortemente apoiados no ideal de igualdade. Nesse sentido, acredita-se que a ênfase no multiculturalismo, enquanto movimento oposto à questão da homogeneidade, faz-se necessária.

A realidade multicultural do planeta se choca com o próprio sistema capitalista imperante, com o fenômeno da globalização que, por um lado, engessa e uniformiza a cultural, mas, por outro lado, permite que culturas diversificadas se aproximem e discutam a imposição monocultural.

As comunidades tradicionais brasileiras formam uma diversidade cultural que está relacionada com a preservação da biodiversidade existente que, em conjunto, representa um vasto patrimônio a ser oferecido às presentes e futuras gerações. São também grupos que desejam seu reconhecimento e respeito, lutam para manter viva a sua cultura e afirmação de sua identidade, bem como para serem valorizados enquanto 'diferentes'.

Dentro desse panorama, a democracia ainda é a fomentadora das discussões, pois permite o acontecimento de debates e questionamentos. E refletir, de- 
bater e discutir sobre a questão do multiculturalismo, compreendendo a importância da diversidade cultural presente nas sociedades contemporâneas, é um ato de extrema urgência no cenário da modernidade.

É justamente a partir do questionamento da democracia pelo multiculturalismo que nasce a necessidade de se reconhecer a diversidade cultural que constitui o espaço público de uma sociedade. Ou seja, a necessidade de reconhecimento da diversidade cultural pelas instituições públicas das sociedades contemporâneas. Logo, a diferença é essencial, dentro do multiculturalismo, para a definição da democracia como um espaço genuinamente heterogêneo.

\section{Constitucionalismo e democracia}

Pode-se definir constitucionalismo, em termos sucintos, como uma técnica específica de controle do exercício do poder com fins garantísticos. ${ }^{4}$ Essa é a vocação essencial do constitucionalismo que, baseado em uma Constituição rígida, pode impor limites ao exercício do poder.

O princípio da constitucionalidade ou da supremacia da Constituição constitui a ideia central do constitucionalismo, implicando a sujeição do conjunto do ordenamento jurídico aos ditames constitucionais, cuja expressão máxima é a rigidez constitucional.

Para o constitucionalismo democrático, o espaço da deliberação democrática deve estar limitado pelos valores substantivos plasmados na Constituição. Isso quer dizer que a deliberação democrática não pode ir contra os direitos fundamentais garantidos na Constituição. ${ }^{5}$

Em síntese, como diz Barboza: ${ }^{6}$

${ }^{4}$ CANOTILHO, José Joaquim Gomes. Direito constitucional e teoria da constituição. 7. ed. Coimbra: Almedina, 2003. p. 51.

5 BARBOZA, Estefânia Maria de Queiroz. A legitimidade democrática da jurisdição constitucional na realização dos direitos fundamentais sociais. 2005. 184 p. Dissertação (Mestrado em Direito)-Pontifícia Universidade Católica do Paraná, Curitiba. p. 16.

6 BARBOZA, Estefânia Maria de Queiroz. A legitimidade democrática da jurisdição constitucional na realização dos direitos fundamentais sociais. 2005. 184 p. Dissertação (Mestrado em Direito)-Pontifícia Universidade Católica do Paraná, Curitiba. p. 43. 
O constitucionalismo tem como pedra angular, os direitos fundamentais, que, por sua vez, representam os valores substantivos escolhidos pela sociedade no momento constituinte - de máxima manifestação da soberania popular - que garantem o funcionamento da democracia, isto é, quando os direitos fundamentais impõem limites materiais aos atos de governo, estão na verdade a proteger o povo como um todo e não apenas maiorias eventuais. E quem está incumbido de proteger estes valores é o Poder Judiciário, conforme determinação do próprio Poder Constituinte.

Já a democracia se faz presente na ideia de que o povo é o detentor da soberania, pois pode eleger livremente seus representantes que, por sua vez, retratarão os seus anseios em um Congresso, Assembleia ou Parlamento.

Quando se analisa a democracia, o primeiro pensamento que vem à tona é a questão do governo da maioria. O voto majoritário é a característica essencial e fundamental da democracia representativa, o que por óbvio não é suficiente para garantir decisões corretas, justas e racionais, vez que o princípio majoritário não assegura igualdade política, ou o bem de todos. ${ }^{7}$

Exatamente por essa questão é que o governo da maioria, nos Estados Constitucionais, deve respeitar e conviver com os direitos das minorias. No contexto ora estudado, entende-se por minorias as comunidades tradicionais, formadas por uma pluralidade que também demanda proteção.

E é justamente a questão do direito das minorias, dentro de um governo de maiorias, que eleva a tensão já existente entre democracia e constitucionalismo. Isso porque o constitucionalismo acaba por limitar a liberdade de deliberação dos representantes eleitos pelo povo, que, por sua vez não podem elaborar leis que afrontem os direitos das minorias, ou mesmo os individuais elencados na Constituição. ${ }^{8}$

Logo, democracia só é democrática se for constitucional, mas a vontade ilimitada da eventual maioria, sem se atentar para o direito das minorias, torna-se

\footnotetext{
BARBOZA, Estefânia Maria de Queiroz. A legitimidade democrática da jurisdição constitucional na realização dos direitos fundamentais sociais. 2005. 184 p. Dissertação (Mestrado em Direito)-Pontifícia Universidade Católica do Paraná, Curitiba. p. 20-21.

8 BARBOZA, Estefânia Maria de Queiroz. A legitimidade democrática da jurisdição constitucional na realização dos direitos fundamentais sociais. 2005. 184 p. Dissertação (Mestrado em Direito)-Pontifícia Universidade Católica do Paraná, Curitiba. p. 20.
} 
ditadura, negando a própria ideia de democracia. Do mesmo modo, o constitucionalismo só é constitucional se for democrático. A elaboração ou a apropriação técnico-burocrática do texto constitucional para moldar passivamente o povo como seu objeto, como objeto do Estado e como massa é autoritarismo e, assim, a negação do próprio constitucionalismo. ${ }^{9}$

A democracia não é o mero governo da maioria. Tem necessariamente que respeitar as posições e os anseios das minorias. O conceito de povo não se confunde com o de maioria, já que a maioria pode estabelecer uma ditadura. $\mathrm{O}$ conceito de povo deverá ser entendido como a soma de maioria e minoria.

Logo, a democracia, para ser democrática, requer o respeito como um todo, englobando, inclusive, o respeito ao direito das minorias. Há que ser garantida institucionalmente, portanto, a possibilidade de que a minoria seja protegida indistintamente. A teoria democrática avançou até esse ponto a partir de experiências bastante dramáticas, como o nazismo, o fascismo, o stalinismo e outros movimentos autoritários. ${ }^{10}$

Por outro lado, a democracia não deixa de ser um dos componentes da interação social que transforma o Estado de Direito. Uma sociedade será mais democrática á medida que haja maior número de atores participando das decisões políticas, e isso inclui a reivindicação de direitos pelas comunidades tradicionais. ${ }^{11}$

Para que a democracia se desenvolva, é necessário que haja ligação entre atores sociais e agentes políticos, que a representatividade social dos governados seja garantida e esteja associada à limitação dos poderes e à consciência da cidadania.

A democracia, entendida como a busca da liberdade, está apoiada na responsabilidade dos cidadãos. Da responsabilidade sobre os atos políticos nasce a

9 CARVALHO NETO, Menelick de. Racionalização do ordenamento jurídico e democracia: a consolidação das leis e o aperfeiçoamento da democracia. Revista Brasileira de Estudos Políticos, Belo Horizonte, n. 88, p. 15, dez. 2003.

${ }^{10}$ CARVALHO NETO, Menelick de. Racionalização do ordenamento jurídico e democracia: a consolidação das leis e o aperfeiçoamento da democracia. Revista Brasileira de Estudos Políticos, Belo Horizonte, n. 88, p. 16, dez. 2003.

${ }^{11}$ PENA, Fernando Marques. Democracia, direitos humanos e globalização. Revista Espaço Acadêmico, ano 6, n. 64, set. 2006. Disponível em: <http://www.espacoacademico.com. br/064/64pena.htm>. Acesso em: 05 ago. 2009. 
representatividade. Os cidadãos devem reconhecer seus interesses nos atos do governo, ou este será estranho e artificial à sociedade.

As minorias, em uma sociedade democrática, devem ser reconhecidas como portadoras de direitos universais e, ao mesmo tempo, de direitos à afirmação e defesa da sua identidade. Esse tratamento dispensado pela maioria à minoria necessita de um espírito democrático e que pressuponha um reconhecimento de si e um reconhecimento do outro em suas diferenças e especificidades socioculturais.

Nas palavras de Pena: ${ }^{12}$

Como sobreviveria uma minoria que não lutasse pela defesa de sua identidade? Provavelmente se descaracterizaria, se diluiria. Mas o que fazer quando há choque entre os direitos fundamentais e os direitos costumeiros da minoria? O que tem prioridade: ser um membro da minoria ou ser cidadão? A sociedade deve garantir o direito universal do cidadão, acrescido dos direitos específicos da minoria, ou seja, o direito à diferença.

O processo de construção democrática implica a criação de espaços sociais de lutas. Distingue-se da cidadania passiva - aquela que é outorgada pelo Estado como ideia moral de tutela e de favor - da cidadania ativa, aquela que institui o cidadão como portador de direitos e deveres, mas, essencialmente, criador de direitos para abrir espaços de participação e possibilitar a emergência de novos sujeitos políticos. ${ }^{13}$

Portanto, nessa linha de pensamento, além de governo constitucional da maioria, com fundamento na igualdade e liberdade, deve tornar-se a democracia, assim, garantidora também dos próprios direitos da minoria. Numa convivência democrática, é preciso que os homens não imponham uns aos outros e à força o seu próprio modo de pensar e de sentir. ${ }^{14}$

${ }^{12}$ PENA, Fernando Marques. Democracia, direitos humanos e globalização. Revista Espaço Acadêmico, ano 6, n. 64, set. 2006. Disponível em: <http://www.espacoacademico.com. br/064/64pena.htm>. Acesso em: 05 ago. 2009.

${ }^{13}$ PENA, Fernando Marques. Democracia, direitos humanos e globalização. Revista Espaço Acadêmico, ano 6, n. 64, set. 2006. Disponível em: <http://www.espacoacademico.com. br/064/64pena.htm>. Acesso em: 05 ago. 2009.

${ }^{14}$ PAUPÉRIO, Arthur Machado. Teoria democrática do estado. 3. ed. Rio de Janeiro: Forense Universitária, 1997. p. 43. 
Assim, por mais erros ou desajustes que possam ser identificados na teoria democrática, ela é, atualmente, o campo de maior discussão de ideias multiculturais. A democracia é o espaço que permite o debate para o seu próprio e contínuo aperfeiçoamento, até porque já é sabido que, em sociedades plurais, não se permite mais uma única voz, uma estrutura centralizada e dominante.

Tudo implica em uma abertura total da democracia que não pode estar apenas baseada em representividade, no direito ao voto. É necessário olhar e agir a favor de direitos supra-individuais, abrindo campo para um pluralismo social como condição de existência de uma democracia participativa. ${ }^{15}$ Democracia sem respeito pelas minorias não é a rigor democracia.

\section{Multiculturalismo: um desafio contemporanêo}

A tendência capitalista que primou pela homogeneização social e cultural se manteve em algumas partes do mundo, entretanto, não conseguiu apagar ou sufocar totalmente as diferenças existentes, sendo certo que a utopia igualitária ${ }^{16}$ não chegou ao seu destino final.

A sociedade contemporânea é extremamente diversa e complexa, apresentando-se a diferença em todos os setores da vida humana ou natureza, sendo inútil contra ela lutar. Justamente por isso é que se pode visualizar que a lógica simplista da igualdade entre todos e o projeto universalista da modernidade se mostraram falhos, porque não foram capazes em dar respostas às diversas reivindicações de diferentes povos e culturas que começaram a surgir.

O multiculturalismo emerge, portanto, como indicador da crise do projeto da modernidade, que abre uma perspectiva crítica de tratamento das principais categorias filosóficas, políticas e sociais que integram o processo de questionamento ao nível das reivindicações multiculturais e do próprio conceito de diferença.

Surgem novas discussões e questionamentos acerca dos modelos científicos, jurídicos, políticos, sociais e econômicos existentes que podem ser considera-

\footnotetext{
${ }^{15}$ MOUFFE, Chantal. O regresso do político. Lisboa: Gradiva, 1996. p. 23.

${ }^{16}$ CITADINO, Gisele. Pluralismo, direito e justiça distributiva. 3. ed. Rio de Janeiro: Lumen Juris, 2004. p. 75.
} 
dos como fundamentos para a crise do projeto universalista da modernidade e que demandam, pela reformulação de tal projeto, como requisito fundamental para o reconhecimento a valorização multicultural.

Neste ínterim, é visível a necessidade de se reformular o projeto da modernidade com especial atenção para a emergência do reconhecimento da valorização multicultural. Neste sentido, Semprini ${ }^{17}$ analisa e destaca as deficiências do projeto:

Construído a partir de um "universalismo" que era com freqüência apenas um disfarce de uma monocultura sob os traços de um simulacro de humanidade incrivelmente branca e européia; estruturado a partir de um espaço público "igualitário" que na verdade fechava as portas a numerosos grupos sociais; fundamentado sobre a noção de individuo abstrata e redutora; submisso à experiência real da diversidade; enfrentando reivindicações de reconhecimento radicais; sofrendo tensões pelas pressões exercidas nos limites do espaço público; fragilizado enfim pelas mudanças ocorridas no coração mesmo deste espaço, o projeto da modernidade dificilmente poderá dar uma resposta coerente ao impasse multicultural se não for profundamente reformulado.

Nessa seara, é valido destacar que o termo multiculturalismo tem o intuito de designar a coexistência de formas culturais ou de grupos caracterizados por culturas diferentes no seio das sociedades modernas. É um modo de descrever as diferenças culturais em um contexto global. Visa o reconhecimento institucional dos direitos dos diferentes valores e aspectos culturais presentes numa sociedade:

[...] é a expressão da afirmação e da luta pelo reconhecimento desta pluralidade de valores e diversidade cultural no arcabouço institucional do Estado democrático de direito, mediante o reconhecimento dos direitos básicos dos indivíduos enquanto seres humanos e o reconhecimento das 'necessidades particulares' dos indivíduos enquanto membros de grupos culturais específicos. Trata de afirmar, como direito básico e universal que os cidadãos têm necessidade de um contexto cultural seguro para dar significado e orientação a seus modos de conduzir a vida; que a pertença a uma comunidade cultural é fundamental para a autonomia individual; que a cultura com seus valores e suas vinculações normativas, representa um importante campo de reconhecimento para os indivíduos

${ }^{17}$ SEMPRINI, Andrea. Multiculturalismo. Bauru, SP: EDUSC, 1999. p. 160-161. 
e que, portanto, a proteção e respeito às diferenças culturais apresenta-se como ampliação do leque de oportunidades de reconhecimento. ${ }^{18}$

Esse multiculturalismo designa a "coexistência de formas culturais ou de grupos caracterizados por culturas diferentes no seio de sociedades modernas"19 Destaca-se que o multiculturalismo reconhece a existência de uma pluralidade cultural dentro de um mesmo Estado Nacional, rompendo com o dogma do povo único da modernidade.

Em outras palavras, trata-se do multiculturalismo emancipatório, baseado no "reconhecimento da diferença e do direito à diferença e da coexistência ou construção de uma vida em comum além de diferenças de vários tipos”. ${ }^{20}$

A questão multicultural está presente em todos os países caracterizados por instituições democráticas e populações heterogêneas, como no Brasil, sociedade totalmente diversificada, mas que ainda permite a imposição de uma cultura sobre a outra.

No multiculturalismo, existe a convivência, em um país, região ou local específico, de diferentes culturas e tradições, há uma mescla de culturas, de visões de vida e de valores. O multiculturalismo é pluralista, como já se pôde observar, pois aceita diversos pensamentos sobre um mesmo tema, abolindo o pensamento único. Há o diálogo entre culturas diversas para a convivência pacífica e com resultados positivos a ambas.

O termo multiculturalismo começou a ser usado em meados da década de 1970. E quanto mais as sociedades crescem e se tornam complexas, mais aumentam os contatos culturais e as tensões decorrentes da miscigenação e do intercâmbio existente.

${ }^{18}$ COSTA, Sérgio; WERLE, Denílson Luís. Reconhecer as diferenças: liberais, comunitários e as relações raciais no Brasil. In: WARREN, Ilse Scherer. Cidadania e multiculturalismo: a teoria social no Brasil contemporâneo. Lisboa: UFSC, 2000. p. 82.

${ }^{19}$ SANTOS, Boaventura de Souza; NUNES, João Ariscado. Introdução: para ampliar o cânone do reconhecimento, da diferença e da igualdade. In: SANTOS, Boaventura de Souza (Org.). Reconhecer para libertar: os caminhos do cosmopolitismo multicultural. Rio de Janeiro: Civilização Brasileira, 2003. p. 26.

${ }^{20}$ SANTOS, Boaventura de Souza; NUNES, João Ariscado. Introdução: para ampliar o cânone do reconhecimento, da diferença e da igualdade. In: SANTOS, Boaventura de Souza (Org.). Reconhecer para libertar: os caminhos do cosmopolitismo multicultural. Rio de Janeiro: Civilização Brasileira, 2003. p. 33. 
A diferença é um componente estrutural da vida social, e o multiculturalismo deve impulsionar a construção de um novo paradigma para as relações sociais, por meio de uma postura emancipatória, e não mais na forma de uma assimilação capitalista.

Sobre o tema, deve-se atentar não somente para a possibilidade de realização, mas também para a forma de concretização. O desenvolvimento econômico global ameaça a cultura pela assimilação econômica. O processo de globalização provoca, por um lado, a homogeneização das culturas e, por outro, pode ser um importante caminho para a construção de novos paradigmas emancipatórios.

A nova economia do capitalismo global, nascida em virtude da realização da globalização econômica pelos países capitalistas, empresas multinacionais e instituições financeiras globais, na busca pelo livre comércio, na realidade, apenas aumentaram a pobreza e a desigualdade social, por meio do processo de exclusão social, não só de pessoas ou cidades, mas também de diversas regiões do globo.

A doutrina do capitalismo global era a lógica da expansão econômica, pautada na ideia de que o crescimento econômico faria diminuir a pobreza, uma vez que os benefícios chegariam a todas as pessoas em razão do aumento do livre comércio. Ocorre que, na prática, isso não acontece, agravando as situações de pobreza.

Paralelamente à globalização, houve um forte processo de uniformidade cultural, com a massificação de padrões de cultura. Entretanto, de forma alternativa, vem surgindo uma tendência contra a hegemonia globalizante do mercado, resultado da própria prática do processo de globalização, pois este permite a aproximação entre culturas. Como exemplo, citam-se os movimentos de preservação ambiental e diversidade cultural no mundo, os quais se abrem em busca do coletivo e lutam contra uma globalização hegemônica.

Outrossim, essas novas concepções voltadas ao coletivo somente têm lugar em um âmbito democrático e participativo. Da mesma forma, ocorre com as questões que envolvem as minorias e comunidades tradicionais, objeto específico deste estudo. O multiculturalismo surge, portanto, como um desafio para as democracias liberais, apoiadas em ideias de igualdade. No entanto, deve-se mencionar que não se deseja apenas a afirmação da diferença por si só, pois isso pode servir de justificativa para a exclusão, inferiorização e discriminação dos 'diferentes'. 
A partir dessa tensão entre igualdade e diferenças, é possível buscar um multiculturalismo democrático como política capaz de reconhecer a singularidade de cada cultura, ampliando o diálogo e aliando princípios constitucionais de dignidade e de respeito à diversidade cultural. E a democracia, em que pese os diversos problemas existentes, é ainda o campo onde podem ser sustentadas ideias multiculturais, já que é o espaço em que se permite o debate e, consequentemente, o aperfeiçoamento de ideais.

Para Taylor, a democracia introduziu a política de reconhecimento igualitário, entretanto, a importância do reconhecimento foi se modificando e aumentando a partir da noção de identidade individual. A identidade pressupõe que cada ser humano possui características próprias, que são formadas e negociadas nas relações com os outros, dando reconhecimento dessa identidade pelos outros, uma importância fundamental. ${ }^{21}$

A democracia é a forma de governo em que o poder político pertence aos cidadãos. A democracia impede a tirania, protege os direitos fundamentais, garante uma estrutura em que a liberdade pode se tornar realidade e possibilita a um povo ou nação conquistar sua autodeterminação. A cidadania implica num processo democrático de participação, desenvolvimento humano, igualdade política e responsabilidade social. Na construção de uma sociedade democrática, que possibilite o livre desenvolvimento de uma cidadania efetivamente inclusiva, capaz de permitir uma esfera de participação de todos e dos Novos Sujeitos Coletivos, é essencial o diálogo, o debate público e a reflexão. Assim, produzem-se as condições essenciais para ampliar e multiplicar os espaços de liberdade, igualdade, pluralismo e solidariedade. ${ }^{22}$

Todavia, não basta apenas a manutenção do sistema da democracia representativa, no direito de voto, é preciso ir além. É preciso agir em prol de direitos supraindividuais, provocando um pluralismo social combativo. "[...] no sentido de lutas emancipatórias que não cabem mais dentro da formatação capitalista, ocidental e pretensamente universalista".23

${ }^{21}$ TAYLOR, Charles. Multiculturalismo. Lisboa: Instituto Piaget, 1997. p. 50.

22 SANTOS, Valdoir da Silva. O multiculturalismo, o pluralismo jurídico e os novos sujeitos coletivos no Brasil. 2006. 408 p. Dissertação (Mestrado em Direito)0 Universidade Federal de Santa Catarina, Florianópolis. p. 189.

${ }^{23}$ SILVA, Letícia. Borges da. Multiculturalismo e biodiversidade: um desafio ao direito vigente. 2007. 122 p. Dissertação (Mestrado em Direito)-Pontifícia Universidade Católica do Paraná, Curitiba. p. 61. 
De acordo, Santos ${ }^{24}$ explicita que:

O capitalismo não é criticável por não ser democrático, mas por não ser suficientemente democrático. [...] A renovação da teoria democrática assenta, antes de mais, na formulação de critérios democráticos de participação política que não confinem esta ao acto de votar. Implica, pois, uma articulação entre democracia representativa e democracia participativa. Para que tal articulação seja possível é, contudo, necessário que o campo do político seja radicalmente redefinido e ampliado.

Mouffe ${ }^{25}$ destaca:

O projeto da democracia radical tem de tentar defender a democracia e expandir a sua esfera de aplicabilidade a novas relações sociais, tendo como objectivo criar um outro tipo de articulação entre os elementos da tradição democrática liberal, já não enquadrando os direitos numa perspectiva individualista, mas concebendo-os como direitos democráticos. [...] Aquilo que necessitamos é de uma hegemonia de valores democráticos, o que exige uma multiplicação de práticas democráticas, institucionalizandoas num número cada vez mais diverso de relações sociais, de forma que possa ser constituída uma multiplicidade de posições de sujeito a partir de uma matriz democrática.

Logo, uma democracia radical exige a desistência da falta de diferenciação do ser humano. As comunidades tradicionais clamam pela expressão da diferença ante uma perspectiva universalista dominante. A democracia radical, proposta por Mouffe, exige que reconheçamos a diferença - o particular, o múltiplo, o heterogêneo. ${ }^{26}$

\section{Multiculturalismo na constituição federal de 1988}

A influência do multiculturalismo está presente não apenas na proteção das criações e manifestações culturais dos diferentes grupos sociais e étnicos formadores da sociedade brasileira, mas permeia também a preocupação do legislador

\footnotetext{
${ }^{24}$ SANTOS, Boaventura de Souza. Pela mão de Alice: o social e o político na pós-modernidade. 7. ed. São Paulo: Cortez, 2000. p. 270-271.

${ }^{25}$ MOUFFE, Chantal. O regresso do político. Lisboa: Gradiva, 1996. p. 33.

${ }^{26}$ MOUFFE, Chantal. O regresso do político. Lisboa: Gradiva, 1996. p. 27.
} 
constituinte em assegurar direitos culturais e territoriais às comunidades tradicionais. $^{27}$

O multiculturalismo procura descrever a existência de uma diversidade de culturas no mundo que coexistem e se influenciam mutuamente, tanto dentro como fora de um mesmo Estado-nação. Como projeto político, aponta para a celebração ou reconhecimento dessas diferenças culturais. As versões emancipatórias do multiculturalismo estão baseadas no reconhecimento e no direito à diferença, assim como na construção de uma vida em comum, além das diferenças. ${ }^{28}$

Durante séculos, afirmou-se que ser humano 'bom' era o homem branco, saudável, rico, cristão, heterossexual e alfabetizado. Diferentemente, indígenas, mulheres, negros, não cristãos, homossexuais, portadores de necessidades especiais, pobres e analfabetos foram, e muitas vezes ainda continuam sendo, considerados seres inferiores por não corresponderem aos padrões culturalmente impostos pelo mundo ocidental.

O multiculturalismo vem justamente questionar essa hierarquização do ser humano, propondo o respeito de todas as minorias existentes numa sociedade.

Na America Latina, o multiculturalismo encontrou sua tradução no mundo jurídico constitucional com o surgimento de constituições que passaram a reconhecer o caráter multicultural e pluriétnico dos países latino-americanos.

As novas constituições foram surgindo com forte caráter pluricultural, multiétnico e preservador da biodiversidade. Como destaca Souza Filho: ${ }^{29}$

Ao lado do individualismo homogeneizador, reconheceuse um pluralismo repleto de diversidade social, cultural e natural, numa perspectiva que se pode chamar de socioambiental. Os sistemas jurídicos constitucionais, antes fechados ao reconhecimento da pluriculturalidade e da multietnicidade, foram reconhecendo, um a um, que os países do continente têm uma variada formação étnica e cultural, e que cada grupo humano que esteja organizado

\footnotetext{
${ }^{27}$ SANTILLI, Juliana. Socioambientalismo e novos direitos. São Paulo: Peirópolis, 2005. p. 79-80.

${ }^{28}$ SANTILLI, Juliana. Socioambientalismo e novos direitos. São Paulo: Peirópolis, 2005. p. 80.

${ }^{29}$ SOUZA FILHO, Carlos Frederico Marés de. Multiculturalismo e direitos coletivos. In: SANTOS, Boaventura de Souza (Org.). Reconhecer para libertar: os caminhos do cosmopolitismo multicultural. Rio de Janeiro: Civilização Brasileira, 2003. p. 93.
} 
segundo sua cultura e viva segundo a sua tradição, em conformidade com a natureza da qual participa, tem direito à opção de seu próprio desenvolvimento.

Há, portanto, a quebra do paradigma constitucional individual, o surgimento da natureza coletiva dos direitos das comunidades tradicionais, como indígenas, quilombolas etc. Abre-se o caminho para a possibilidade de sobrevivência do multiculturalismo em um mundo no qual o Estado reconhece apenas os direitos individuais.

A Constituição Federal de 1988 segue o paradigma multicultural, pois reconheceu direitos territoriais e culturais às comunidades tradicionais, rompendo com o modelo integracionista, assimilacionista e homogeinizador. Ganharam força as noções constitucionais de titularidade coletiva de direitos, uso e posse compartilhados de recursos naturais e territórios e de respeito às diferenças culturais. ${ }^{30}$

E a orientação multicultural da Constituição Federal de 1988 se dá justamente no reconhecimento de direitos coletivos das comunidades tradicionais, enquanto povos culturalmente diferenciados. A Constituição, em relação aos povos indígenas, por exemplo, rompeu definitivamente com a ideologia integracionista que existia.

Antes da referida Constituição, era possível observar que em todas as constituições, projetos e emendas, a intenção do governo brasileiro era sempre de integrar o índio à comunidade nacional, aniquilando a cultura indígena e desrespeitando as suas diferenças. ${ }^{31}$

É a primeira vez, no Brasil, que uma Constituição estabelece novos elementos jurídicos para fundamentar as relações entre os índios e os não índios e garantir a manutenção de seus direitos diante da sociedade nacional.

O artigo 231 da Constituição Federal de 1988 que trata, especificamente, sobre a questão indígena, é incisivo no sentido da adoção do pluralismo, vez que reconhece a organização social indígena, seus costumes e tradições. Acabam-se as perspectivas integracionistas e assimilacionistas, reconhecendo-se aos índios sua

\footnotetext{
${ }^{30}$ SANTILLI, Juliana. Socioambientalismo e novos direitos. São Paulo: Peirópolis, 2005. p. 82.

${ }^{31}$ COLAÇO, Thais Luzia. Os novos direitos indígenas. In: WOLKMER, Antonio Carlos; LEITE, José Rubens Morato (Org). Os novos direitos no Brasil. São Paulo: Saraiva, 2003. p. 86.
} 
multietnicidade, o usufruto exclusivo sobre os recursos naturais existentes em suas terras e a posse permanente das terras que tradicionalmente ocupam, permitindo ou não o acesso de terceiros.

Logo, o Estado Democrático de Direito instituído pela Constituição e fundamentado na cidadania, dignidade da pessoa humana e no pluralismo político, tendo como objetivos fundamentais a construção de uma sociedade justa, solidária e livre de discriminação, demonstra por completo o seu inegável aspecto multicultural, pluralista e coletivo.

Nesse sentido, Souza Filho ${ }^{32}$ menciona que:

A Constituição abre as portas para o reconhecimento da jurisdição indígena, quer dizer ao reconhecimento das normas internas que regem as sociedades indígenas e os processos pelos quais se dedicam os conflitos por ventura ocorrentes. Mais alguns passos e os povos indígenas poderão, em seus idiomas tradicionais, exercer entre seus membros seu direito tradicional.

Portanto, a Constituição Federal de 1988, possuidora de um caráter inovador e democrático, protegeu a diversidade cultural e cedeu espaço para a afirmação do pluralismo jurídico e de um Estado Multicultural. ${ }^{33}$

Por outro lado, é fato que, em certas situações, o reconhecimento diferenciado de grupos minoritários, mais precisamente de comunidades tradicionais que é a análise específica deste estudo, pode entrar em confronto com o próprio regime democrático e o principio da dignidade da pessoa humana.

$\mathrm{Na}$ realidade, este é o ponto mais nevrálgico da discussão do relativismo cultural, ou seja, quando o reconhecimento de um padrão diverso de cultura e, portanto, da democracia e direitos humanos, implica em ferir de morte o estado democrático de direito e a dignidade da pessoa humana.

O que deve prevalecer ou como fazer uma ponderação de valores? Existem, para tanto, os mais variados caminhos e, por óbvio, o presente estudo não tem a

\footnotetext{
32 SOUZA FILHO, Carlos Frederico Marés de. O renascer dos povos indígenas para o direito. Curitiba: Juruá, 1998. p. 162.

${ }^{33}$ SILVA, Letícia. Borges da. Multiculturalismo e biodiversidade: um desafio ao direito vigente. 2007. 122 p. Dissertação (Mestrado em Direito)-Pontifícia Universidade Católica do Paraná, Curitiba. p. 110.
} 
pretensão de responder tal questão, mas apenas indicar que é mediante o discurso entre as culturas (diálogo intercultural) que se pode chegar a uma conclusão satisfatória.

Taylor $^{34}$ explica que cada ser humano tem a sua maneira original de ser, na sua própria medida e enfatiza que:

Antes do final do século XVIII, ninguém havia pensado que as diferenças entre seres humanos pudessem assumir este tipo de importância moral. Existe uma determinada maneira de ser humano que é a minha maneira. Sou obrigado a viver a minha vida de acordo com essa maneira, e não imitando a vida de outra pessoa.

É justamente essa maneira própria e original de ser de diversos grupos minoritários, com identidades diferenciadas, que não deve ser oprimida. Os fundamentos dos ideais do multiculturalismo têm o condão de introduzir uma nova concepção na busca pelo respeito à dignidade da pessoa humana e direitos humanos.

O modelo universalista que pugna por uma sociedade homogênea promove de certa forma, o isolamento cultural e, consequentemente, não valoriza a diversidade cultural das comunidades tradicionais. A luta dessas comunidades deve ocorrer num espaço em que a atividade nacional e a identidade cultural não apareçam como contraditórias, mas complementares na construção de uma sociedade multicultural, justa e democrática.

É, pois, necessária a realização de um diálogo intercultural, no qual haja reciprocidade entre as culturas e que os problemas de colisão entre um e outro possam ser partilhados no cenário mundial, ensejando alianças nas lutas emancipatórias.

Nessa concepção, impõe-se o referido diálogo intercultural baseado em uma hermenêutica diatópica ${ }^{35}$ como forma de, a partir da consciência de sua própria incompletude, ampliar o diálogo entre culturas.

\footnotetext{
${ }^{34}$ TAYLOR, Charles. Multiculturalismo. Lisboa: Instituto Piaget, 1997. p. 50.

${ }^{35}$ SANTOS, Boaventura de Souza; NUNES, João Ariscado. Introdução: para ampliar o cânone do reconhecimento, da diferença e da igualdade. In: SANTOS, Boaventura de Souza (Org.). Reconhecer para libertar: os caminhos do cosmopolitismo multicultural. Rio de Janeiro: Civilização Brasileira, 2003.
} 


\section{Considerações finais}

A proposta da modernidade impôs um caráter homogeinizador à humanidade, pautado em padrões sempre igualitários. Ocorre que a superfície do planeta é composta de várias culturas, raças e gêneros completamente diferentes que começaram a exigir o seu reconhecimento.

Não tardou, para que lutas emancipatórias e reivindicações baseadas em ideais multiculturais começassem a surgir no cenário mundial. Tais ideais primam pelo reconhecimento da diferença e da diversidade, apontando a necessidade de que culturas sejam respeitadas em suas manifestações próprias, sem qualquer tipo de fragmentação ou homogeneização cultural.

A perspectiva multicultural promove a preservação de identidades, o enriquecimento que advém de considerar posições e vivências alheias, de saber dar e receber, de exprimir e escutar opiniões, em suma, de assumir na prática uma interculturalidade.

Reconhecer e respeitar as comunidades tradicionais, aprofundando noção de democracia, constitui uma premissa básica para se atingir a verdadeira emancipação desses povos, bem como para garantir que seus direitos culturais sejam respeitados pelo Estado Democrático de Direito.

O desejo das comunidades tradicionais está apoiado numa consciência de origem, numa identidade cultural e étnica que abre caminhos e motiva a luta pela emancipação democrática e pela conquista de espaço e reconhecimento.

A participação das comunidades tradicionais nas discussões e debates favorece a construção de um país e de um regime político democrático com base num pluralismo social, político e cultural que considera e respeita as diferentes concepções e a diversidade cultural.

Somente uma concepção pluralista e multicultural pode se refletir, positivamente, na história e na sociedade, porque acolhe a diversidade cultural e social, assim como oferece uma perspectiva de representação mais autêntica para os grupos culturalmente diferenciados e comunidades tradicionais, num processo heterogêneo e complexo de formação sociopolítica da sociedade democrática.

Hoje, o multiculturalismo é um dos maiores desafios impostos ao Estado, em razão da própria diversidade cultural e dos conflitos dentro de um país em 
busca de uma unidade social. Isso traz à baila a necessidade da incorporação dessas diferenças pelos sistemas democráticos atuais, bem como a necessidade de desmistificar uma pretensa homogeneidade cultural construída, primando pelo respeito à 'diferença'.

Logo, a construção da identidade e proteção à cultura diferenciada dos grupos culturalmente diversos, em especial as comunidades tradicionais, deve ser promovido por meio do diálogo intercultural. O respeito e a tolerância devem permear as discussões em âmbito democrático, visando assim à construção de uma nação multicultural.

\section{Constitutionalism $x$ democracy: the multiculturalism and traditional communities}

\section{Abstract}

This paper analyzes the emergence of multiculturalism as a challenge for liberal democracies backed the idea of equality. It aims at a democratic multiculturalism as a policy capable of recognizing the uniqueness of each culture, expanding the dialogue, respect and allying itself with the constitutional principles of dignity and respect for cultural diversity. Despite the number of minorities embrace multiculturalism, the present study will be restricted to the analysis of the issue from the perspective of traditional communities, they, in turn, claim the state and society to recognize their rights. The emergence of these claims of various culturally diverse groups arises from a universalist perspective inadequate and unable to contemplate the different social identities and perform one of the cornerstones of democracy is the principle of equality for all. These groups are fighting for the right to be different and refuse the idea of world capitalism and bureaucratic, imposing standards of behavior and values essentially discriminatory and exclusionary. Our society is in possession of vast cultural diversity, and the difference is presented as a structural component of social life that needs to be further harmonized with the multicultural aspect of people. It follows, hence, that democracy, despite various problems, is still the field in which ideas can be sustained multicultural as it is a space where discussions are allowed, and consequently the improvement of ideals. The value and originality of work are related to the proposed radicalize democracy, 
emphasizing the need to incorporate the differences by democratic systems today, and the need to demystify an alleged cultural homogeneity built.

Keywords: Constitutionalism. Democracy. Traditional communities. Multiculturalism.

\section{Referências}

BARBOZA, Estefânia Maria de Queiroz. A legitimidade democrática da jurisdição constitucional na realização dos direitos fundamentais sociais. Dissertação de Mestrado em Direito - Pontifícia Universidade Católica do Paraná, Curitiba, 2005, $184 \mathrm{p}$.

CANOTILHO, José Joaquim Gomes. Direito constitucional e teoria da constituição. 7. ed. Coimbra: Almedina, 2003.

CARVALHO NETO, Menelick de. Racionalização do ordenamento jurídico e democracia: a consolidação das leis e o aperfeiçoamento da democracia. Revista Brasileira de Estudos Políticos, Belo Horizonte, n. 88, dez. 2003.

CITADINO, Gisele. Pluralismo, direito e justiça distributiva: elementos da filosofia constitucional contemporânea. 3. ed. Rio de Janeiro: Lumen Júris, 2004.

COLAÇO, Thais Luzia. Os novos direitos indígenas. In: WOLKMER, Antonio Carlos; LEITE, José Rubens Morato (Org). Os novos direitos no Brasil. São Paulo: Saraiva, 2003.

COSTA, Sérgio; WERLE, Denílson Luís. Reconhecer as diferenças: liberais, comunitários e as relações raciais no Brasil. In: WARREN, Ilse Scherer. Cidadania e multiculturalismo: a teoria social no Brasil contemporâneo. Lisboa: UFSC, 2000.

MOUFFE, Chantal. O regresso do político. Lisboa: Gradiva, 1996.

PAUPÉRIO, Arthur Machado. Teoria democrática do estado. 3. ed. Rio de Janeiro: Forense Universitária, 1997.

PENA, Fernando Marques. Democracia, direitos humanos e globalização. Revista Espaço Acadêmico, ano 6, n. 64, set. 2006. Disponível em: <http://www. espacoacademico.com.br/064/64pena.htm>. Acesso em: 05 ago. 2009.

SANTILLI, Juliana. Socioambientalismo e novos direitos. São Paulo: Peirópolis, 2005. 
SANTOS, Boaventura de Souza. Pela mão de Alice: o social e o político na pósmodernidade. 7. ed. São Paulo: Cortez, 2000.

SANTOS, Boaventura de Souza; NUNES, João Ariscado. Introdução: para ampliar o cânone do reconhecimento, da diferença e da igualdade. In: SANTOS, Boaventura de Souza (Org.). Reconhecer para libertar: os caminhos do cosmopolitismo multicultural. Rio de Janeiro: Civilização Brasileira, 2003.

SANTOS, Valdoir da Silva. O multiculturalismo, o pluralismo jurídico e os novos sujeitos coletivos no Brasil. 2006. 408 p. Dissertação (Mestrado em Direito)Universidade Federal de Santa Catarina, Florianópolis, 2006.

SEMPRINI, Andrea. Multiculturalismo. Bauru, SP: EDUSC, 1999.

SILVA, Letícia. Borges da. Multiculturalismo e biodiversidade: um desafio ao direito vigente. 2007. 122 p. Dissertação (Mestrado em Direito)-Pontifícia Universidade Católica do Paraná, Curitiba, 2007.

SILVÉRIO, Roberto Valter. O multiculturalismo e o reconhecimento: mito e metáfora. Revista da USP: Pós-Modernidade e Multiculturalismo, n. 42, 1999.

SOUZA FILHO, Carlos Frederico Marés de. Multiculturalismo e direitos coletivos. In: SANTOS, Boaventura de Souza (Org.). Reconhecer para libertar: os caminhos do cosmopolitismo multicultural. Rio de Janeiro: Civilização Brasileira, 2003.

SOUZA FILHO, Carlos Frederico Marés de. O renascer dos povos indígenas para o direito. Curitiba: Juruá, 1998.

TAYLOR, Charles. Multiculturalismo. Lisboa: Instituto Piaget, 1997. 
